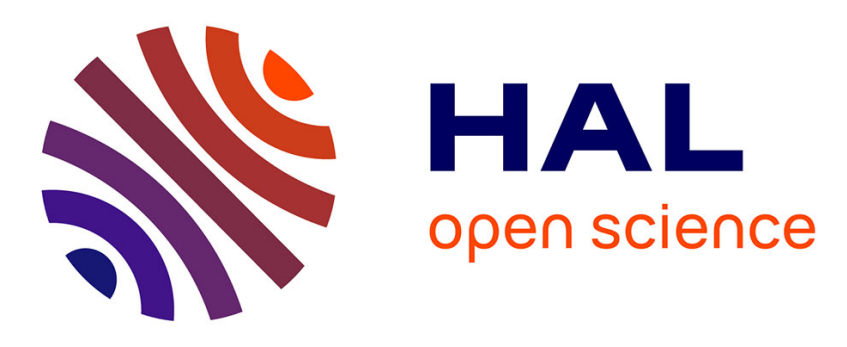

\title{
Storage conditions of the mafic and silicic magmas at Cotopaxi, Ecuador
}

\author{
Caroline Martel, Joan Andújar, Patricia Mothes, Bruno Scaillet, Michel \\ Pichavant, Indira Molina
}

\section{- To cite this version:}

Caroline Martel, Joan Andújar, Patricia Mothes, Bruno Scaillet, Michel Pichavant, et al.. Storage conditions of the mafic and silicic magmas at Cotopaxi, Ecuador. Journal of Volcanology and Geothermal Research, 2018, 354, pp.74-86. 10.1016/j.jvolgeores.2018.02.006 . insu-01707763

\section{HAL Id: insu-01707763 https://hal-insu.archives-ouvertes.fr/insu-01707763}

Submitted on 13 Feb 2018

HAL is a multi-disciplinary open access archive for the deposit and dissemination of scientific research documents, whether they are published or not. The documents may come from teaching and research institutions in France or abroad, or from public or private research centers.
L'archive ouverte pluridisciplinaire HAL, est destinée au dépôt et à la diffusion de documents scientifiques de niveau recherche, publiés ou non, émanant des établissements d'enseignement et de recherche français ou étrangers, des laboratoires publics ou privés. 


\section{Accepted Manuscript}

Storage conditions of the mafic and silicic magmas at Cotopaxi, Ecuador

Caroline Martel, Joan Andújar, Patricia Mothes, Bruno Scaillet, Michel Pichavant, Indira Molina

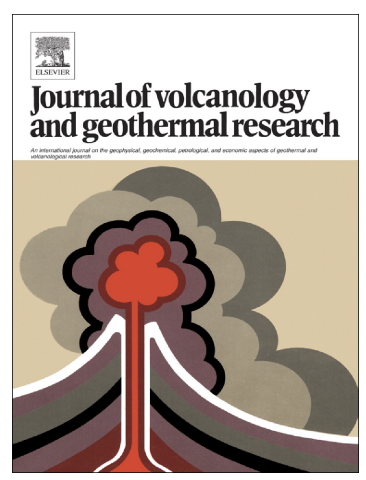

PII: S0377-0273(17)30624-8

DOI: https://doi.org/10.1016/j.jvolgeores.2018.02.006

Reference: VOLGEO 6305

To appear in: Journal of Volcanology and Geothermal Research

Received date: 12 October 2017

Revised date: 30 January 2018

Accepted date:

6 February 2018

Please cite this article as: Caroline Martel, Joan Andújar, Patricia Mothes, Bruno Scaillet, Michel Pichavant, Indira Molina, Storage conditions of the mafic and silicic magmas at Cotopaxi, Ecuador. The address for the corresponding author was captured as affiliation for all authors. Please check if appropriate. Volgeo(2017), https://doi.org/10.1016/ j.jvolgeores.2018.02.006

This is a PDF file of an unedited manuscript that has been accepted for publication. As a service to our customers we are providing this early version of the manuscript. The manuscript will undergo copyediting, typesetting, and review of the resulting proof before it is published in its final form. Please note that during the production process errors may be discovered which could affect the content, and all legal disclaimers that apply to the journal pertain. 


\title{
Storage conditions of the mafic and silicic magmas at Cotopaxi, Ecuador
}

\section{Caroline MARTEL ${ }^{a}$, Joan ANDÚJAR ${ }^{a}$, Patricia MOTHES ${ }^{b}$, Bruno SCAILLET ${ }^{a}$, Michel PICHAVANT ${ }^{a}$, Indira MOLINA ${ }^{b}$}

\author{
${ }^{a}$ Institut des Sciences de la Terre d'Orléans (ISTO), Université d'Orléans-CNRS-BRGM, \\ Orléans, France \\ ${ }^{\mathrm{b}}$ Instituto Geofísico, Escuela Politécnica Nacional (IGEPN), Quito, Ecuador
}

\begin{abstract}
The 2015 reactivation of the Cotopaxi volcano urges us to understand the complex eruptive dynamics of Cotopaxi for better management of a potential major crisis in the near future. Cotopaxi has commonly transitioned from andesitic eruptions of strombolian style (lava flows and scoria ballistics) or nuées ardentes (pyroclastic flows and ash falls) to highly explosive rhyolitic ignimbrites (pumiceous pyroclastic flows), which entail drastically different risks. To better interpret geophysical and geochemical signals, Cotopaxi magma storage conditions were determined via existing phase-equilibrium experiments that used starting materials chemically close to the Cotopaxi andesites and rhyolites. The results suggest that Cotopaxi's most mafic andesites (last erupted products) can be stored over a large range of depth from $\sim 7$ $\mathrm{km}$ to $\geq 16 \mathrm{~km}$ below the summit (pressure from $\sim 200$ to $\geq 400 \mathrm{MPa}$ ), $1000{ }^{\circ} \mathrm{C}, \mathrm{NNO}+2$, and contain 4.5-6. $0_{ \pm 0.7} \mathrm{wt} \% \mathrm{H}_{2} \mathrm{O}$ dissolved in the melt in equilibrium with $\sim 30-40 \%$ phenocrysts of plagioclase, two pyroxenes, and Fe-Ti oxides. These mafic andesites sometimes evolve towards more silicic andesites by cooling to $950{ }^{\circ} \mathrm{C}$. Rhyolitic magmas are stored at 200-300 $\mathrm{MPa}$ (i.e. $\sim 7-11 \mathrm{~km}$ below the summit), $750{ }^{\circ} \mathrm{C}$, $\mathrm{NNO}+2$, and contain $\sim 6-8 \mathrm{wt} \% \mathrm{H}_{2} \mathrm{O}$ dissolved in a nearly aphyric melt (less than $5 \%$ phenocrysts of plagioclase, biotite, and Fe-Ti oxides). Although the andesites produce the rhyolitic magmas by fractional crystallization, the Cotopaxi eruptive history suggests reactivation of either reservoirs at distinct times, likely reflecting flux or time fluctuations during deep magma recharge.
\end{abstract}

Keywords: Cotopaxi; andesite; rhyolite; experimental petrology; eruptive dynamics 


\section{Introduction}

After 13 significant eruptions since 1534, a major eruption in 1877, and a VEI 1 eruption in 1949, Cotopaxi volcano started to reactivate in 2001-2002 (Kumagai et al., 2010; Molina et al., 2008). In August 2015, phreatomagmatic eruptions followed four months of precursory activity including a major seismic crisis (Gaunt et al., 2016). Although this crisis was small to moderate in intensity and ash volume erupted $\left(8.6 \times 10^{5} \mathrm{~m}^{3}\right.$; Bernard et al., 2016), this does not preclude a major magmatic crisis in the near future. The densely populated surroundings of the volcano make the monitoring and forecasting of the volcano's activity of highest priority and urge us to understand the complex eruptive dynamics of Cotopaxi. Therefore, the present study focusses on the understanding of the magma genesis and storage conditions below Cotopaxi.

\subsection{Geological setting}

The Cotopaxi volcano results from the eastward subduction of the oceanic Nazca Plate beneath the continental South American Plate, with an estimated dip of $25-35{ }^{\circ} \mathrm{C}$ and a depth to the slab beneath the arc front of $\sim 100-150 \mathrm{~km}$ (Taboada et al., 2000; Font et al., 2013). From north to south of the South American continent, this subduction zone defines four volcanic zones (the Northern, Central, Southern, and Austral Volcanic Zones) and generates two parallel mountain regions from east to west (the Eastern and Western Cordilleras). The Cotopaxi volcano belongs to the Eastern Cordillera of the Northern Volcanic Zone in the Ecuadorian Andes, located $60 \mathrm{~km}$ south of Quito and $35 \mathrm{~km}$ northeast of Latacunga (Fig. 1A). The volcano has a massive conical shape (22 km diameter) culminating at $5897 \mathrm{~m}$ high, with steep flanks capped with a glacier. The crustal thickness beneath the Cordillera of the Northern Volcanic Zone is estimated $\sim 70 \mathrm{~km}$ (Feininger and Seguin, 1983; Taboada et al., 2000; Araujo, 2016), and is one of the thickest north of the Central Andes.

\subsection{Cotopaxi eruptive dynamics and magma compositions}

Cotopaxi has long been considered as an andesitic volcano of strombolian-type erupting scoria ballistics and lava flows associated with large lahars, based on its 1534 to present activity. However, Hall and Mothes (2008) revealed the importance of Cotopaxi rhyolitic volcanism that generated large pumiceous pyroclastic flows and ash fallouts starting $560 \mathrm{kyr}$ 
ago. In fact, Cotopaxi has been commonly alternating strombolian andesitic eruptions with rhyolitic ignimbrites (pyroclastic flows), without generating intermediate (dacitic) magma compositions. There is no systematic trend towards more or less evolved magma through time, although the frequency of rhyolitic eruptions is greater in the earlier Cotopaxi edification stage than in the recent period. To reconcile magma fractionation (from basaltic andesite to rhyolite) over long storage timescales ( $74 \mathrm{kyr}$, determined by U-series data; Garrison et al., 2006) with the high frequency of the rhyolitic eruptions (separated by $\sim 2 \mathrm{kyr}$ ), Garrison et al. (2011) proposed a long-lived rhyolitic reservoir partially tapped at repeated intervals. Because either eruptive style (strombolian or siliceous pyroclastic flows and ash falls) entails drastically different hazards and risk assessment, the prerequisite is to understand the plumbing system beneath Cotopaxi (number of reservoirs, storage depths, and volatile contents), the petrogenetic relationships between the different magmas and the mechanisms that control the eruptive dynamics.

\subsection{Stratigraphy}

The stratigraphy of Cotopaxi deposits has been defined by Hall and Mothes (2008) and is summarized in Fig. 1B. The eruptive deposits are divided into Cotopaxi I and II sequences. Cotopaxi I lasted from 420 to $560 \mathrm{kyr}$ and is characterized by $\sim 10 \mathrm{~km}^{3}$ DRE deposits of rhyolitic ignimbrites and ash falls called the Barrancas series (paleo-Cotopaxi edifice). The overlaying Chalupas Ignimbritic series ( 100 $\left.\mathrm{km}^{3} \mathrm{DRE}\right)$, dated to $211 \mathrm{kyr}$ and produced by the Chalupas caldera's paroxysmal eruption $15 \mathrm{~km}$ to the southeast, marks the transition to the younger Cotopaxi II sequence. This sequence is divided into the lower Cotopaxi IIA units dated from $\sim 13-20$ to $4.5 \mathrm{kyr}$ BP and the upper Cotopaxi IIB (to present). The Cotopaxi IIA section alternates rhyolitic ignimbrites, such as the F-series (five major eruptions of about 6 $\mathrm{km}^{3}$ DRE total volume) with andesitic scoria and lava flows. Erupted volumes slowly increase with time (total of $\sim 1-2 \mathrm{~km}^{3} \mathrm{DRE}$ ) and end with a major flank collapse event. The Cotopaxi IIA is separated from the Cotopaxi IIB section by the Colorado Canyon Ignimbrite dated to $4.5 \mathrm{kyr}$ BP $\left(\sim 1 \mathrm{~km}^{3}\right.$ DRE). The Cotopaxi IIB sequence comprises a series of andesitic scoria falls and lava flows $\left(\sim 7 \mathrm{~km}^{3} \mathrm{DRE}\right)$, with minor rhyolitic episodes occurring $\sim 2.2 \mathrm{kyr} \mathrm{BP}$ called the Peñas Blancas rhyolites ( $\left.\sim 0.6 \mathrm{~km}^{3} \mathrm{DRE}\right)$. From the stratigraphy, it thus appears that Cotopaxi was more rhyolitic and explosive at the beginning of its edification, turning into more mafic and effusive with time (even if the recent activity still shows sparse Plinian episodes of rhyolitic magmas). The historical activity, mainly reported in chronicles and 
reports and summarized in Pistolesi et al. (2011), consists of VEI 2 to 4 eruptions of scoriarich flows and falls and lava flows, such as those of 1534, 1742, 1768, 1877 and 1880 (all representing 1-3 km³ DRE; Hall and Mothes, 2008). The Quilotoa volcano emitted a very distinctive dacitic biotite-bearing ash fall deposit dated to $810 \mathrm{yr}$ BP (Hall and Mothes, 2008) that has been used as a date marker for the younger Cotopaxi deposits.

\subsection{Objectives and approach}

Below, magma storage conditions for Cotopaxi will be constrained by using phaseequilibrium experiments on magma compositions different from but close to those present on the volcano. Instead of acquiring a full set of experimental data over a broad field of conditions for the various Cotopaxi magmas (an approach that necessarily requires time), we make use of already existing experimental studies. The whole approach can thus be viewed as a guided interpolation and extrapolation of experimental data. The main motivation is to test if, with this approach, results can be made available rapidly to help interpreting daily acquisition of geophysical and geochemical signals. Phase-equilibrium data for specific magma compositions emitted at a given volcano might not directly apply elsewhere and, so, we are ready to accept larger uncertainties in determined storage conditions than, for example, with the direct experimental approach. However, this choice is made for the benefit of a faster response, an important issue in the case of volcanic unrest.

\section{Sample geochemistry and petrology}

The whole-rock major-elements geochemistry and petrology of the Cotopaxi samples come from Garrison et al. (2011), with some additional analyses for the historical eruptions from Pistolesi et al. (2011) (both determined by inductively coupled plasma-mass spectroscopy). In Garrison et al. (2011), minerals and matrix glasses were analyzed by electron microprobe. Here, new mineral and glass analyses are provided, as well as glass $\mathrm{H}_{2} \mathrm{O}$ contents for one sample from the andesitic 1877 eruption and one pumice from the Peñas Blancas rhyolitic eruption (SX-five electron microprobe; ISTO, Orléans; Supplementary Material SM1). The compilation of the whole-rock major-elements data confirms two distinct magma compositions: andesite ( $\left.\sim 56-62 \mathrm{wt} \% \mathrm{SiO}_{2}\right)$ and rhyolite $\left(\sim 70-76 \mathrm{wt} \% \mathrm{SiO}_{2}\right)$, with a chemical gap between 62 and $70 \mathrm{wt} \% \mathrm{SiO}_{2}$ (Fig. 2). 


\subsection{Andesites}

\subsubsection{Whole-rock composition}

The andesite group shows a significant scatter from 56 to $64 \mathrm{wt} \% \mathrm{SiO}_{2}$ and from $\sim 2$ to nearly $5 \mathrm{wt} \% \mathrm{MgO}$ (Fig. 2). Within this group, there is an interesting difference in eruptive style between, on the one hand, the $\mathrm{SiO}_{2}$-poorer and $\mathrm{MgO}$-richer magmas that erupt as strombolian-type and lava flows and, on the other hand, the $\mathrm{SiO}_{2}$-richer and $\mathrm{MgO}$-poorer magmas that erupt explosively as pumiceous pyroclastic flows and ash falls. Therefore, two contiguous groups have been defined: one with $\mathrm{MgO}<2.5 \mathrm{wt} \%$ and $\mathrm{SiO}_{2}>60 \mathrm{wt} \%$, hereafter referred as Si-andesites (e.g. the Peñas Blancas andesite eruption) and the other with $\mathrm{MgO}$ of 3-5 wt\% and $\mathrm{SiO}_{2}<60 \mathrm{wt} \%$, hereafter referred as Mg-andesites (e.g. the 1877 eruption). Interestingly, both magma compositions (and hence both eruptive styles) are present within a given edification sequence (Cotopaxi IIA or IIB), even among recent eruptions (the post 1130 AD layers mainly contain $\mathrm{Si}$-andesite pumices whereas the other eruptions are mostly $\mathrm{Mg}$ andesite scoria; Pistolesi et al., 2011). The most recent Cotopaxi magmas are the most mafic (rich in $\mathrm{MgO}$ and poor in $\mathrm{SiO}_{2}$ ).

\subsubsection{Phenocrysts}

All Cotopaxi andesites, whether pumice or lava/scoria, contain 23 to 48 modal\% phenocrysts (Garrison et al., 2011). The phenocrysts are mainly plagioclase ( 80\% recalculated on a bubble-free basis), orthopyroxene, clinopyroxene, and minor Fe-Ti oxides (magnetite \pm ilmenite) (SM2).

The plagioclases in both $\mathrm{Mg}$ - and Si-andesites show compositions from 45 to $95 \mathrm{~mol} \%$ anorthite $\left(\mathrm{An}_{45-95}\right)$, with a main frequency mode at $\sim \mathrm{An}_{55-65}$ (Fig. 3A). Garrison et al. (2011) noted little compositional variation between cores and rims. Our new plagioclase analytical profiles of $1877 \mathrm{Mg}$-andesite crystals show complex zoning, commonly spanning a total compositional range of $\mathrm{An}_{45-70}$, with rim compositions around $\mathrm{An}_{55-60}$ (except for one crystal with a $A n_{76-87}$ profile either inherited from more mafic compositions or reheated; Fig. 4). Phenocryst rim compositions have more chances to represent chemical equilibrium with the melt just prior to eruption, following the 'local equilibrium' concept of Pichavant et al. (2007). No analytical profiles were performed on Si-andesite plagioclases, but limited ( $\mathrm{n}=$ 13) punctual analyses show that the most sodic compositions that could represent plagioclase rims are $\mathrm{An}_{55-60}$ (Fig. 3A). 
The orthopyroxenes in the Si-andesites show a narrow compositional range of $66-72 \mathrm{~mol} \%$ enstatite $\left(\operatorname{En}_{66-72} ; \mathrm{n}=9\right)$, with a main mode at $\mathrm{En}_{68-72}$. The $\mathrm{Mg}$-andesites span a large compositional range from $\mathrm{En}_{60}$ to $\mathrm{En}_{78}$, with a main frequency mode at $\mathrm{En}_{68-72}$ similar to that in Si-andesites (Fig. 3B). Punctual rim analyses and profiles show rim compositions of $\mathrm{En}_{68-70}$ in Si-andesites and $\mathrm{En}_{72-74}$ in $\mathrm{Mg}$-andesites. For both andesite groups, clinopyroxenes have between 38 to $45 \mathrm{~mol} \%$ wollastonite ( $\mathrm{Wo}_{38-45}$ ), with a main frequency mode at $\mathrm{Wo}_{41-43}$ (Fig. 3B). In Mg-andesites, clinopyroxene rim compositions are $\mathrm{Wo}_{41-42} \mathrm{En}_{41-42}$ (e.g. SM1 for the $1877 \mathrm{AD}$ eruption) and, for Si-andesites, $\mathrm{Wo}_{43-44} \mathrm{En}_{40-45}$. Both pyroxenes show similar $\mathrm{Mg}$ numbers $(\mathrm{Mg} \#=$ molar $\mathrm{Mg} /(\mathrm{Fe}+\mathrm{Mg}))$ of $0.74_{ \pm 0.02}$ and $0.72_{ \pm 0.03}$ for the $\mathrm{Mg}$ - and $\mathrm{Si}$-andesites, respectively.

Magnetites in Si-andesites show restricted compositions from 72 to 75 mol\% magnetite $\left(\mathrm{Mt}_{72-75}\right)$, with a main mode at $\mathrm{Mt}_{73-74}$. In $\mathrm{Mg}$-andesites, magnetites show a slightly wider range $\left(\mathrm{Mt}_{70-77}\right)$ and a bimodal distribution, with the main mode at $\mathrm{Mt}_{75-76}$ and a secondary mode at $\mathrm{Mt}_{72-74}$ that overlaps with Si-andesites (Fig. 3C). Traces of ilmenite occur in both andesites.

\subsubsection{Composition and $\mathrm{H}_{2} \mathrm{O}$ content of the glass inclusions and matrix glasses}

Glass inclusions are mostly hosted in pyroxenes, with typical size of 10-30 $\mu \mathrm{m}$ in diameter, and they contain rare bubbles and small amounts of iron-rich daughter minerals (i.e. Fe-Ti or $\mathrm{Fe}-\mathrm{Mg}$ minerals; SM2D). The matrix glasses and glass inclusions in the Mg-andesites show extremely variable compositions from 60 to $75 \mathrm{wt} \% \mathrm{SiO}_{2}$ (Fig. 5), essentially filling the bulkrock compositional gap (Fig. 2). A group of matrix glasses in a Mg-andesite lava (CTX-75 identified as 'lava' in Garrison et al., 2011) has extremely $\mathrm{SiO}_{2}$-rich compositions (78-82 wt\% $\mathrm{SiO}_{2}$; from the 'Old andesite $\mathrm{MG}^{\prime}$ group in Fig. 5). Such silica-rich glasses may result from cooling-induced extensive microlite crystallization during lava flow emplacement (i.e. they differ from the matrix glasses analyzed in microlite-poor pumice or scoria). However, even if values above $75 \mathrm{wt} \% \mathrm{SiO}_{2}$ are exceptional, glasses still cover a wide range of composition $\left(62-72 \mathrm{wt} \% \mathrm{SiO}_{2}\right)$. The matrix glasses for one of the 1877 samples range between 62 and 64 wt $\% \mathrm{SiO}_{2}$ and are thus more mafic than the glass inclusions (63-70 wt\% $\left.\mathrm{SiO}_{2} ; \mathrm{SM} 1\right)$. This, together with rounded phenocrysts and skeletal $\sim \mathrm{An}_{60}$ microlites (SM2D; SM1), suggests a mixing event involving a more mafic and hot liquid just before eruption. If the time lapse between recharge and eruption is short, the mixing may only occur between both matrixes (resident andesite and newly injected liquid), without significantly incurring modifications of the phenocryst rims, as proposed by Martel et al. (2006). Consequently, the residual glasses 
analyzed in the erupted products are not in chemical equilibrium with the phenocryst rims, and may be more mafic than the glass inclusions. The $64-67 \mathrm{SiO}_{2} \mathrm{wt} \%$ matrix glasses in ashes identified as juvenile material from the 2015 phreatomagmatic eruption (Gaunt et al., 2016) show trends in some oxides (e.g., $\mathrm{Al}_{2} \mathrm{O}_{3}, \mathrm{CaO}, \mathrm{FeO}$ ) that deviate from a crystal fractionation trend (Fig. 5), possibly reflecting some mixing effects comparable to those in 1877.

The glasses have been analyzed for their volatile content (assumed to be $\mathrm{H}_{2} \mathrm{O}$ ), using the electron microprobe and different standard glasses of dacitic and rhyolitic compositions for which the $\mathrm{H}_{2} \mathrm{O}$ content is well-known (data and methods in SM1). The glass inclusions hosted in pyroxenes from the $1877 \mathrm{Mg}$-andesite show $\mathrm{H}_{2} \mathrm{O}$ contents from 0.8 to $3.5_{ \pm 0.7} \mathrm{wt} \%$, without significant differences whether hosted in orthopyroxene $\left(\mathrm{En}_{68}\right.$ to 70$)$ or clinopyroxene $\left(\mathrm{Wo}_{38}\right.$ to 44; Fig. 6). Matrix glasses in the $1877 \mathrm{Mg}$-andesite have $\mathrm{H}_{2} \mathrm{O}$ contents $\leq 1.0 \mathrm{wt} \%$ (SM1), but the reheated nature of this sample makes them suspicious.

\subsection{Rhyolites}

The whole-rock geochemistry of the rhyolites all comes from Garrison et al. (2011). Fig. 2 shows that Cotopaxi IIB Peñas Blancas rhyolites have compositions similar to Cotopaxi IIA F-series. All rhyolites contain 2-4\% phenocrysts of plagioclase, biotite, and minor amounts of quartz, magnetite, ilmenite, apatite, allanite, and zircon (SM2A). Amphibole is reported in the last and least-evolved F-series deposits (F4, sample CTX19 in Garrison et al., 2011). It is lacking in the Peñas Blancas rhyolites and the Barrancas series of Cotopaxi_I's early edification stage, although some younger units of this latter series show traces of amphibole, K-feldspar, and pyroxenes (Hall and Mothes, 2008). Mineral chemistry data are available for the F-series (Garrison et al., 2011), with some additional data for the Peñas Blancas rhyolites (SM1). The plagioclase composition ranges from $\mathrm{An}_{27}$ to $\mathrm{An}_{52}$, showing a main frequency mode at $\mathrm{An}_{30-35}$ (Fig. 3A) that corresponds to rim compositions (Fig. 4). The magnetite compositional range is narrow, from $\mathrm{Mt}_{83}$ to $\mathrm{Mt}_{86}$, showing a main frequency mode at $\mathrm{Mt}_{84-85}$ (Fig. 3C). Ilmenites have $77_{ \pm 4}$ mol\% ilmenite ( $\left(\operatorname{llm}_{77_{ \pm}}\right.$). Biotite compositions show 2.1 to 2.4 mol\% $\mathrm{Al}$ and $\mathrm{Mg} \#$ from 0.5 to $0.7\left(\mathrm{Bt}_{0.5-0.7}\right)$. In the F-series, $\mathrm{Wo}_{41-42}$ clinopyroxenes (Fig. 3B) and amphiboles containing $11 \mathrm{wt} \% \mathrm{Al}_{2} \mathrm{O}_{3}\left(\mathrm{Am}_{11}\right), 1.6-1.8 \mathrm{pfu} \mathrm{Al}^{\mathrm{IV}}, 0.4-0.5$ pfu cations in the alkali (A) site, and $\mathrm{Mg \#} \sim 0.66_{ \pm 0.02}$ (Fig. 7) have been found. The matrix glasses have $\mathrm{SiO}_{2}$ contents from 75 to 81 wt\% (Fig. 5; n.b., the scatter in alkali contents likely reflects inappropriate analytical conditions). Unfortunately, we did not find any glass inclusion in the phenocrysts. 
The ignimbrites from Chalupas Caldera (not belonging to Cotopaxi edifice) and Colorado Canyon Series (unclear origin) show comparable whole-rock geochemistry (Fig. 2). Both ignimbrites have $\mathrm{K}_{2} \mathrm{O}$ contents higher by nearly $2 \mathrm{wt} \%$ compared to the Cotopaxi rhyolites (as well as $\sim 1$ wt $\%$ less $\mathrm{Na}_{2} \mathrm{O}$ and slightly higher $\mathrm{TiO}_{2}$ contents). The Chalupas Caldera ignimbrite and most of the Colorado Canyon ignimbrite show a phenocryst assemblage similar to that of the Cotopaxi rhyolites, although lacking amphibole (except for pristine reaction-free amphibole reported in the least evolved Colorado Canyon ignimbrite; Garrison et al., 2011).

\subsection{Summary}

The Cotopaxi Mg-andesites are characterized by 23 to $42 \%$ phenocrysts made of $\mathrm{An}_{55-60^{-}}$ rimmed plagioclase, $\mathrm{En}_{72-74}$-rimmed orthopyroxene, $\mathrm{WO}_{41-42} \mathrm{En}_{41-42}$ rimmed clinopyroxene (both pyroxenes with $\mathrm{Mg \#} \sim 0.74_{ \pm 0.02}$ ), and $\mathrm{Mt}_{75-76}$, in a $62-72 \mathrm{wt} \% \mathrm{SiO}_{2}$ matrix glass. Glass inclusions contain up to $3.5_{ \pm 0.7} \mathrm{wt} \% \mathrm{H}_{2} \mathrm{O}$.

The Si-andesites are characterized by 23 to $42 \%$ of the same phenocrysts, with slightly different compositions: $\mathrm{An}_{55-60}$ (plagioclase rims), $\mathrm{En}_{68-70}, \mathrm{Wo}_{42-43}$ (both pyroxenes with $\mathrm{Mg \#}$

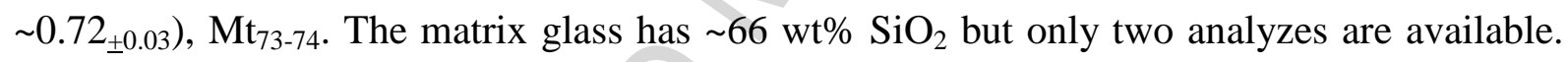
There are no data for glass inclusions and volatile contents.

The rhyolites are characterized by 2-4 \% phenocrysts of $\mathrm{An}_{30-35}$, biotite with $2.1-2.4$ wt $\%$ $\mathrm{Al}_{2} \mathrm{O}_{3}$ and $\mathrm{Mg \#}_{0.5-0.7}, \mathrm{Mt}_{84-85}$, and $\mathrm{Ilm}_{77 \pm 4}$, in a 75-81 wt\% $\mathrm{SiO}_{2}$ matrix glass. $\mathrm{Wo}_{41-42}$ clinopyroxenes and amphibole $\left(11 \mathrm{wt} \% \mathrm{Al}_{2} \mathrm{O}_{3}\right.$ and $\left.\mathrm{Mg \#} 0.66_{ \pm 0.02}\right)$ have been reported. There is no data for glass inclusions and volatile contents.

\section{Crystallization conditions determined from the natural samples}

\subsection{Andesites}

The composition of coexisting orthopyroxene and clinopyroxene can be used to infer crystallization temperatures using two-pyroxene thermobarometry. Using the formulation of Putirka (2008), the pyroxene pairs that passed the test of equilibrium crystallization (based on the Fe-Mg exchange coefficient) suggest temperatures $(T) \sim 980{ }^{\circ} \mathrm{C}$ and pressures $(P) \sim 440$ $\mathrm{MPa}$ for the Si-andesite (one single pair) and $\sim 990-1040{ }^{\circ} \mathrm{C}$ and 565-965 $\mathrm{MPa}$ for the $\mathrm{Mg}$ andesites (SM3A). Using a density of $\sim 2700 \mathrm{~kg} / \mathrm{m}^{3}$ for andesitic rocks, this gives depths of 
$\sim 16$ and 21-36 km below the summit, respectively. Nevertheless, these calculations must be taken with caution, since results on 200-MPa andesitic experimental samples show systematic overestimations of temperature by $\sim 100{ }^{\circ} \mathrm{C}$ and of pressure by $>100 \mathrm{MPa}$ (SM3A).

The composition of the liquid in equilibrium with plagioclase may be used to estimate $T$ and $\mathrm{H}_{2} \mathrm{O}$ content using plagioclase-liquid thermohygrometers. The main difficulty with the Cotopaxi andesites is the compositional scatter of the glasses, either matrix glasses or glass inclusions (Fig. 5). In addition, the glass inclusions are not trapped in plagioclase but in pyroxenes, which does not guarantee plagioclase-liquid equilibrium. Both andesites have plagioclase rims of $\sim \mathrm{An}_{55-60}$ but, depending on the melt composition and $T$ considered, $\mathrm{H}_{2} \mathrm{O}$ contents calculated using the formulation of Water and Lange (2015) vary from 3.3 to $4.9_{ \pm 0.4}$ wt $\% \mathrm{H}_{2} \mathrm{O}$ at $950{ }^{\circ} \mathrm{C}$ and from 1.2 to $2.7_{ \pm 0.4} \mathrm{wt} \% \mathrm{H}_{2} \mathrm{O}$ at $1100{ }^{\circ} \mathrm{C}$. In these calculations performed at $P$ between 200 and $600 \mathrm{MPa}$, the highest bounds correspond to the most silicic (64 wt $\% \mathrm{SiO}_{2}$ ) and the lowest bounds to the most mafic $\left(61 \mathrm{wt} \% \mathrm{SiO}_{2}\right)$ matrix glass compositions (SM3B). Using the glass inclusions, $\mathrm{H}_{2} \mathrm{O}$ contents vary from 3.9 to $4.7_{ \pm 0.4} \mathrm{wt} \%$ $\mathrm{H}_{2} \mathrm{O}$ at $950{ }^{\circ} \mathrm{C}$ and from 1.9 to $2.6_{ \pm 0.4} \mathrm{wt} \% \mathrm{H}_{2} \mathrm{O}$ at $1100{ }^{\circ} \mathrm{C}$ for $\mathrm{SiO}_{2}$ contents between 63 and 75 wt $\%$ and $P$ between 200 and $600 \mathrm{MPa}(\mathrm{SM} 3 \mathrm{~B})$. The maximum $\mathrm{H}_{2} \mathrm{O}$ contents of $3.5_{ \pm 0.7}$ wt $\%$ measured in pyroxene-hosted glass inclusions are consistent with crystallization in a 950- $1100{ }^{\circ} \mathrm{C} T$ range (SM3B).

To summarize, the crystallization conditions retrieved from the andesitic samples suggest $T$ $\sim 950-1100{ }^{\circ} \mathrm{C}$, melt $\mathrm{H}_{2} \mathrm{O}$ content from $\sim 1.2-2.7 \mathrm{wt} \%$ at $1100{ }^{\circ} \mathrm{C}$ to $\sim 3.3-4.9$ wt $\%$ at $950{ }^{\circ} \mathrm{C}$, and poor constraints on pressure. Lack of ilmenite analyses prevented the retrieval of oxygen fugacity $\left(f_{\mathrm{O} 2}\right)$.

\subsection{Rhyolites}

Magnetites and ilmenites that passed the test of chemical equilibrium (Bacon and Hirschman, 1988) suggest $T$ from 728 to $774_{ \pm}{ }^{\circ}{ }^{\circ} \mathrm{C}$ and $f_{\mathrm{O} 2}$ close to $2.0_{ \pm 0.1} \log$ units above the $\mathrm{Ni}-\mathrm{NiO}$ oxygen buffer $\left(\Delta \mathrm{NNO}+2.0_{ \pm 0.1}\right)$ after the calculation of Sauerzapf et al. (2008) (SM3C). The high Mg\# ( 0.5-0.7) in biotite and in amphibole ( 0.7; Fig. 7B) are both consistent with a $f_{\mathrm{O} 2}$ close to $\mathrm{NNO}+1.5$.

Fig. 7A shows that the compositions of amphiboles analyzed in one of the F-series rhyolites (Garrison et al., 2011) are not compatible with crystallization from a rhyolitic liquid at either 100 or $400 \mathrm{MPa}$ (i.e. 4 or $15 \mathrm{~km}$ below the summit). The $\mathrm{Al} / \mathrm{Si}$ ratio of these amphiboles is about 0.32 , which is similar to those of the dacitic interstitial glasses of the 
andesites $\left(\sim 64 \mathrm{wt} \% \mathrm{SiO}_{2}\right.$ and $\sim 17 \mathrm{wt} \% \mathrm{Al}_{2} \mathrm{O}_{3}, \mathrm{SM} 1$; bulk-rocks of rhyolites, Si-andesites, and $\mathrm{Mg}$-andesites show ratios of about $0.24,0.36$, and 0.39 , respectively). Therefore, these amphiboles likely crystallized from a dacitic liquid and were incorporated into the rhyolitic magma. Since they are only reported in the least evolved rhyolitic magmas (i.e., $72 \mathrm{wt} \%$ $\mathrm{SiO}_{2}$ ), it seems to be a peculiarity of low-silica rhyolites that do not represent the majority of the erupted rhyolites at Cotopaxi. Therefore, we will no longer consider amphibole as belonging to the rhyolitic phase assemblage. Similarly, the rare clinopyroxenes found in the F-series rhyolites have the same composition than those of andesites (Fig. 3B), likely reflecting inherited crystals.

The melt $\mathrm{H}_{2} \mathrm{O}$ contents, calculated from the plagioclase-melt geohygrometer of Water and Lange (2015) for a $78_{ \pm 2} \mathrm{wt} \% \mathrm{SiO}_{2}$ matrix glass in equilibrium with $\mathrm{An}_{30-37}$, range from 3.8$4.3_{ \pm 0.4} \mathrm{wt} \%$ at $900{ }^{\circ} \mathrm{C}, 6.1-6.6_{ \pm 0.4} \mathrm{wt} \%$ at $800{ }^{\circ} \mathrm{C}$ to $9.3-9.6_{ \pm 0.4} \mathrm{wt} \%$ at $700{ }^{\circ} \mathrm{C}$ ( $P$ from 200 to $600 \mathrm{MPa}$; SM3B). Use of the RHYO-MELTS software is not appropriate for the Cotopaxi rhyolites since alkali feldspar is virtually absent and biotite is present.

To summarize, the crystallization conditions retrieved from the rhyolite phase compositions suggest $T$ of $728-774_{+50}{ }^{\circ} \mathrm{C}$ and $f \mathrm{O}_{2}$ close to $\mathrm{NNO}+2$. For $T$ between 700 and $800{ }^{\circ} \mathrm{C}$, calculated melt $\mathrm{H}_{2} \mathrm{O}$ contents vary from 6 to $9 \mathrm{wt} \%$. $P$ remains unconstrained.

\section{Phase equilibria}

To refine magma crystallization conditions constrained from the natural samples, phaseequilibrium experiments performed on natural magmas different but very close to the Cotopaxi Mg-andesite, Si-andesite, and rhyolite will be analyzed below. The selection of candidate experimental studies was guided by two main criteria. (i) The first is the composition used as starting material which must approach Cotopaxi magmas since a 1-2 wt\% difference in major elements such as $\mathrm{SiO}_{2}, \mathrm{Al}_{2} \mathrm{O}_{3}, \mathrm{CaO}$, alkalis $\left(\mathrm{Na}_{2} \mathrm{O}\right.$ and $\left.\mathrm{K}_{2} \mathrm{O}\right), \mathrm{FeO}_{\mathrm{t}}$ or $\mathrm{MgO}$ is enough to significantly change the phase assemblage and crystallization sequence (see for instance Cadoux et al., 2014). (ii) The second is the $P-T-f_{\mathrm{O} 2}-f_{\mathrm{H} 2 \mathrm{O}}$ conditions covered in candidate studies which must encompass the range expected for magma storage at Cotopaxi. Compositions of minerals and melts must also have been determined in candidate studies since their dependence with experimental variables provides the most precise constraints on crystallization conditions (e.g. Rutherford et al., 1985). For this reason, only redox-controlled studies were considered because $f_{\mathrm{O} 2}$ directly affects experimental compositions (e.g. Martel et al., 1999). 
In the selected experimental studies, the water concentration is expressed in various ways. To allow comparison between them all, the initial mole fraction of $\mathrm{H}_{2} \mathrm{O}\left(X_{\mathrm{H} 2 \mathrm{Oin}}\right)$ will be used below instead of the water activity $\left(a_{\mathrm{H} 2 \mathrm{O}}\right)$ or the melt water content $\left(\mathrm{wt} \% \mathrm{H}_{2} \mathrm{O}\right)$. This is because calculation of $a_{\mathrm{H} 2 \mathrm{O}}$ or wt $\% \mathrm{H}_{2} \mathrm{O}$ depends on the particular $\mathrm{H}_{2} \mathrm{O}$ solubility model chosen. $X_{\mathrm{H} 2 \mathrm{Oin}}$ will eventually be converted into melt $\mathrm{H}_{2} \mathrm{O}$ contents, (i) for rhyolites, by using the $\mathrm{H}_{2} \mathrm{O}$ solubility model of Newman and Lowenstern (2002), with $P \sim P_{\mathrm{H} 2 \mathrm{O}}$ (approximated by $\mathrm{X}_{\mathrm{H} 2 \mathrm{Oin}}{ }^{*} \mathrm{P}_{\text {total }}$ ) and (ii) for Mg-andesites, by measuring $\mathrm{H}_{2} \mathrm{O}$ contents in the experimental charges following the by-difference method of Devine et al. (1995). This last method has the benefit of being that used to measure the $\mathrm{H}_{2} \mathrm{O}$ contents in glass inclusions and it avoids errors when applying solubility models to Mg-andesite melts for which calibration data are lacking.

\subsection{Mg-andesites}

\subsubsection{Selection of experimental studies}

Two experimental studies have been selected on the basis of the criteria above, one performed on the Mg-rich andesite of the August 2006 Tungurahua eruption, Ecuador (TUN; Andújar et al., 2017) and the other on the andesite of the Unzen 1991-95 eruption, Japan (UNZ; Botcharnikov et al., 2008). Both andesites show $\mathrm{MgO}, \mathrm{SiO}_{2}, \mathrm{Al}_{2} \mathrm{O}_{3}, \mathrm{CaO}, \mathrm{FeO}$, and $\mathrm{K}_{2} \mathrm{O}$ contents consistent with Cotopaxi Mg-andesites (Fig. 2). Yet, both andesites comparatively lack $\sim 0.5 \mathrm{wt} \% \mathrm{Na}_{2} \mathrm{O}$, but still compare in terms of total alkali $\left(\mathrm{Na}_{2} \mathrm{O}+\mathrm{K}_{2} \mathrm{O}\right)$ content (Fig. 2). The phase equilibria have been determined at NNO-0.5 for $\boldsymbol{U N Z}$ and NNO+1 and NNO+2 for $\boldsymbol{T U N}$. Using experimental phase relationships and compositions from these studies, we seek for $P-T-f_{\mathrm{O} 2}-f_{H 2 O}$ conditions that simultaneously yield $23-48 \mathrm{wt} \%$ crystals of $\mathrm{An}_{55-60}, \mathrm{Wo}_{40-41}, \mathrm{En}_{72-74}$ and $\mathrm{Mt}_{75-76}$ in a $62-72 \mathrm{wt} \% \mathrm{SiO}_{2}$ liquid containing up to $3.5_{ \pm 1} \mathrm{wt} \%$ $\mathrm{H}_{2} \mathrm{O}$ (see above). Results are discussed for different pressures/depths below.

\subsubsection{Pressure of $100 \mathrm{MPa} / 4 \mathrm{~km}$ depth}

The $\mathrm{H}_{2} \mathrm{O}$-saturated $\left(X_{\mathrm{H} 2 \mathrm{Oin}}=1\right) \boldsymbol{T U N}$ experiments performed at 975 to $1000{ }^{\circ} \mathrm{C}, \mathrm{NNO}+1$, or $1000{ }^{\circ} \mathrm{C}, \mathrm{NNO}+2$, both crystallized olivine, a phase that does not belong to the Cotopaxi phase assemblage. Clinopyroxenes in $\mathrm{H}_{2} \mathrm{O}$-undersaturated olivine-free charges have Wo contents $\left(<\mathrm{Wo}_{40}\right)$ too low to match those of Cotopaxi andesites. Therefore, the available constraints rule out a $P$ of $100 \mathrm{MPa}$ for $\mathrm{Mg}$-andesite crystallization at Cotopaxi.

\subsubsection{Pressure of $200 \mathrm{MPa} / 7 \mathrm{~km}$ depth}


Both $\boldsymbol{U N Z}$ and $\boldsymbol{T U N}$ phase diagrams have a $T-X_{\mathrm{H} 2 \mathrm{Oin}}$ field at $0<\Delta \mathrm{NNO}<+1$ where the natural Cotopaxi $\mathrm{Mg}$ andesite assemblage is reproduced. For conditions within this field, however, no clinopyroxene has Wo > 40, no orthopyroxene has En > 65 and no magnetite has Mt $>60(\mathrm{SM} 4 \mathrm{~A})$. At $\mathrm{NNO}+2$, the $\boldsymbol{T U N}$ charge at $975{ }^{\circ} \mathrm{C}$ and $X_{\mathrm{H} 2 \mathrm{Oin}} \sim 0.7$ almost reproduces the phenocryst proportion (32\% crystals), assemblage and compositions at Cotopaxi (Fig. 8A). One minor discrepancy concerns clinopyroxene, slightly more En-rich in the experimental charge $\left(\operatorname{En}_{44-48}\right)$ than in Cotopaxi products $\left(\operatorname{En}_{41-42} ;\right.$ Fig. $\left.8 \mathrm{~A}\right)$.

\subsubsection{Pressure of $400 \mathrm{MPa} / 16 \mathrm{~km}$ depth}

At $\mathrm{NNO}+1$, the $\boldsymbol{T U N}$ experiment at $1000{ }^{\circ} \mathrm{C}$ and $X_{\mathrm{H} 2 \mathrm{Oin}} \sim 0.7$ (29 wt\% crystals, SM4B) is very close to reproduce the Cotopaxi phase assemblage and compositions. Magnetites were too small to be analyzed in that charge but, based on results at $200 \mathrm{MPa}$ for the same $f \mathrm{O}_{2}$ (SM4A), their composition (Mt < 60) would imply conditions that are too reduced for Cotopaxi. Yet, experiments at $\mathrm{NNO}+2, T \sim 1000{ }^{\circ} \mathrm{C}$ and $X_{\mathrm{H} 2 \mathrm{Oin}}$ of $0.6-0.7$ yield the appropriate phase assemblage (30 to $\sim 50 \%$ crystals, Fig. $8 \mathrm{~B}$ ) and the Cotopaxi Mg-andesites phenocryst compositions are nearly reproduced. Clinopyroxene in particular has $\operatorname{En}\left(\operatorname{En}_{42-43}\right)$ in closer agreement with the natural compositions than those crystallized at $200 \mathrm{MPa}$.

\subsection{Si-andesites}

\subsubsection{Selection of the experimental studies}

The selected phase-equilibrium studies include those performed on the 1350 AD P1 Plinian eruption of Montagne Pelée, Martinique (PEL; Martel et al., 1999), on the 55-65 ka Upper Scoria Plinian eruption of Santorini, Greece (SAN; Andújar et al., 2016) and on the 28 Ma Huerto lavas emplaced just after the Fish Canyon tuff, Colorado (HUE; Parat et al., 2008). Whereas $\boldsymbol{P E L}$ is quite close to Cotopaxi Si-andesites (but see below), $\boldsymbol{H U E}$ and $\boldsymbol{S A N}$ are both comparatively depleted in $\mathrm{Al}_{2} \mathrm{O}_{3}$ (by 1 and $\sim 2 \mathrm{wt} \%$ respectively) and $\boldsymbol{S A N}$ comparatively enriched in $\mathrm{FeO}_{\mathrm{t}}$ (by $\sim 3-4 \mathrm{wt} \%$, leading to a significantly lower Mg\#) (Fig. 2). Using these studies, we seek for conditions that simultaneously yield 23-48\% crystals of $\mathrm{An}_{55-60}, \mathrm{Wo}_{42-43}, \mathrm{En}_{68-70}, \mathrm{Mt}_{73-74}$, coexisting with a residual liquid with $\sim 66 \mathrm{wt} \% \mathrm{SiO}_{2}$.

\subsubsection{Pressure of $100 \mathrm{MPa} / 4 \mathrm{~km}$ depth}

No $\boldsymbol{P E L}$ and $\boldsymbol{H U E}$ experiments are available at $100 \mathrm{MPa}$ but the phase relationships for $\boldsymbol{S A N}\left(975\right.$ to $1000{ }^{\circ} \mathrm{C}, \mathrm{NNO} \sim+1.5, X_{\mathrm{H} 2 \mathrm{O} i n}$ from 0.3 to 1 ; SM5A) provide several arguments to 
dismiss $100 \mathrm{MPa}$ as a possible crystallization pressure for Cotopaxi Si-andesites. (i) In the 975-1000 ${ }^{\circ} \mathrm{C}$ temperature range, crystallization of plagioclase $<\mathrm{An}_{60}$ requires an experimental crystallinity $>50 \%$ whereas $<50 \%$ is required from natural products. (ii) Experimental clinopyroxene is too low in $\mathrm{Wo}$ content $\left(\sim \mathrm{Wo}_{30-35}\right)$ compared to natural phenocrysts $\left(\mathrm{Wo}_{42-43}\right)$. (iii) Values of $X_{\mathrm{H} 2 \mathrm{Oin}}<0.6$ correspond to $\mathrm{H}_{2} \mathrm{O}$ contents lower than the maximum measured in glass inclusions (up to $3.5_{ \pm 0.7} \mathrm{wt} \%$; note that $3.5 \mathrm{wt} \%$ is the calculated $\mathrm{H}_{2} \mathrm{O}$ solubility at 100 MPa, Newman and Lowenstern, 2002). Nevertheless, the specificities of the $\boldsymbol{S A N}$ composition (more FeO-rich and $\mathrm{Al}_{2} \mathrm{O}_{3}$-poor than Cotopaxi Si-andesites) need consideration. For similar experimental conditions $\left(200 \mathrm{MPa}, 950{ }^{\circ} \mathrm{C}, X_{\mathrm{H} 2 \mathrm{Oin}}=0.73,+1.5<\Delta \mathrm{NNO}<+2.5\right)$, the $\boldsymbol{S A N}$ and $\boldsymbol{P E L}$ results show systematic differences. In the $\boldsymbol{S A N}$ charges, the crystallinity, Wo in clinopyroxene and $\mathrm{En}$ in orthopyroxene are higher by $10 \mathrm{wt} \%, 15 \mathrm{~mol} \%$ and $4 \mathrm{~mol} \%$ respectively than in the PEL charges, and the An in plagioclase is lower by $11 \mathrm{~mol} \%$ (SM5B). Thus, correcting the $100 \mathrm{MPa} \boldsymbol{S A N}$ results leads to crystallinity and plagioclase An content both being closer to Cotopaxi Si-andesites. However, the discrepancy persists (it is in fact worsened) for the clinopyroxene Wo content. Therefore, we conclude that $100 \mathrm{MPa}$ is not a possible crystallization pressure for Cotopaxi Si-andesites.

\subsubsection{Pressure of $200 \mathrm{MPa} / 7 \mathrm{~km}$ depth}

The $\boldsymbol{P E L}$ phase equilibria reproduce the Cotopaxi phase assemblage for $T$ from 850 to 950 ${ }^{\circ} \mathrm{C}, X_{\mathrm{H} 2 \mathrm{Oin}}<0.9$ and for the two $\mathrm{fO}_{2}$ investigated, although the stability field for clinopyroxene is poorly-constrained (SM5B). PEL crystallinities and compositions of plagioclase and glass compare well with Cotopaxi samples. Plagioclases $\left(\mathrm{An}_{55-60}\right)$ are reproduced below $925{ }^{\circ} \mathrm{C}$ $X_{\mathrm{H} 2 \mathrm{Oin}} \sim 0.7$ and at $875^{\circ} \mathrm{C}-X_{\mathrm{H} 2 \mathrm{Oin}} \sim 0.9$. For these conditions, the crystallinity is about $40-48$ $\%$ and the residual glass has 70-73 $\mathrm{wt} \% \mathrm{SiO}_{2}$, both in the upper limits of their respective ranges in Cotopaxi products. In comparison, orthopyroxene and magnetite compositions differ between experimental and natural samples. For instance, for $+2<\Delta \mathrm{NNO}<+3$, the natural $\mathrm{En}_{70}$ orthopyroxenes are well reproduced but experimental magnetites are always $>\mathrm{Mt}_{85}$, i.e., too high for Cotopaxi Si-andesites $\left(\mathrm{Mt}_{74-76}\right)$. Lowering the $f_{\mathrm{O} 2}$ to $0<\Delta \mathrm{NNO}<+1$ generates $\mathrm{Mt}_{74-76}$ magnetites but orthopyroxenes (always $<\mathrm{En}_{68}$ ) become too low in En for Cotopaxi $\left(\mathrm{En}_{70-72}\right)$. This mismatch between experimental and natural phase compositions is, firstly, the consequence of the $f_{\mathrm{O} 2}$ range in the $\boldsymbol{P E \boldsymbol { L }}$ experiments, slightly inappropriate for Cotopaxi. It is most likely that a $f_{\mathrm{O} 2}$ in between the two domains investigated $(+2<\Delta \mathrm{NNO}<+3$ and $0<\Delta \mathrm{NNO}<+1)$ in $\boldsymbol{P E L}$ experiments would yield pyroxene and magnetite compositions in 
better agreement with natural products. Secondly, it is important to stress that $\boldsymbol{P E L}$ has a slightly lower Mg\# (0.26-0.27) than Cotopaxi silicic andesites (e.g., the Peñas Blancas compositions, $\mathrm{Mg} \#=0.31-0.32$; Fig. 2) and, so, for a given $f_{\mathrm{O} 2}$, the $\boldsymbol{P E L}$ experiments underestimate the En content of orthopyroxenes in Cotopaxi magmas. Finally, the rarity of clinopyroxene in the $\boldsymbol{P E L}$ experiments contrasts with its systematic presence in Cotopaxi Siandesites. This inconsistency, which accentuates with pressure since clinopyroxene is absent in $\boldsymbol{P E L}$ experiments at 300 and $400 \mathrm{MPa}$, is most likely of compositional origin. The $\boldsymbol{P E \boldsymbol { L }}$ starting composition is significantly less alkali-rich than the Cotopaxi Si-andesites (Fig. 2), being more calcic than calc-alkaline. In such compositions, crystallization of An-rich plagioclase over clinopyroxene is favoured. Plagioclase is more An-rich, and so, for conditions being equal, the $\boldsymbol{P E \boldsymbol { L }}$ experiments overestimate the An contents in Cotopaxi magmas. Therefore, if $f_{\mathrm{O} 2}$ is adjusted appropriately and the differences between the respective magma compositions considered, the discrepancies between $\boldsymbol{P E L}$ results and natural Siandesite products can be rationalized. We conclude that $200 \mathrm{MPa}$ is a possible crystallization pressure for the Cotopaxi Si-andesites.

\subsubsection{Pressure of $300 \mathrm{MPa} / 11 \mathrm{~km}$ depth}

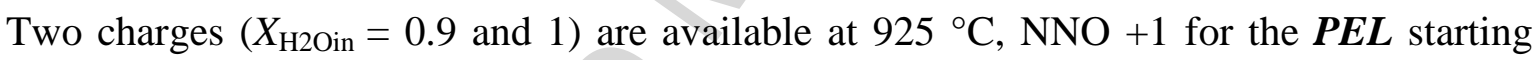
material. The $X_{\mathrm{H} 2 \mathrm{Oin}}=1\left(\mathrm{H}_{2} \mathrm{O}\right.$-saturated $)$ charge has a crystallinity of $20 \%$ and the $X_{\mathrm{H} 2 \mathrm{Oin}}=$ 0.9 of $40 \%$. In natural products, $40 \%$ is a maximum crystallinity and, so, $X_{\mathrm{H} 2 \mathrm{Oin}}=0.9$ is a minimum in the $300 \mathrm{MPa}$ experiments. This corresponds to a $\mathrm{H}_{2} \mathrm{O}$ concentration of $\sim 7 \mathrm{wt} \%$, a minimum which is about twice higher than the maximum $\left(3.5_{ \pm 0.7} \mathrm{wt} \% \mathrm{H}_{2} \mathrm{O}\right)$ measured in the glass inclusions. Therefore, $300 \mathrm{MPa}$ cannot be taken as the crystallization pressure for the Cotopaxi Si-andesite if temperature is fixed at $925{ }^{\circ} \mathrm{C}$. Yet, increasing temperature to $\sim 950{ }^{\circ} \mathrm{C}$ would permit $25-45 \%$ crystallinities at lower $\mathrm{H}_{2} \mathrm{O}$ contents.

\subsubsection{Pressure of $400 \mathrm{MPa} / 16 \mathrm{~km}$ depth}

One set of charges is available for $\boldsymbol{P E L}$ at $930{ }^{\circ} \mathrm{C}, \mathrm{NNO}+1$ for $X_{\mathrm{H} 2 \mathrm{Oin}}$ between 1 and 0.7 . Amphibole crystallizes alone on the liquidus for $X_{\mathrm{H} 2 \mathrm{Oin}}=1$. For lower $X_{\mathrm{H} 2 \mathrm{Oin}}$, amphibole is replaced by a plagioclase and orthopyroxene assemblage. More data are available on the $\boldsymbol{H U E}$ and $\boldsymbol{S A N}$ compositions. The phase diagrams, compiled in Fig. 9 for $\boldsymbol{H U E}$ (NNO) and $\boldsymbol{S A N}$ $(\mathrm{NNO}+1.5)$ as well as for $\boldsymbol{P E} \boldsymbol{L}(\mathrm{NNO}+1)$, define a broad domain $\left(X_{\mathrm{H} 2 \mathrm{Oin}}<0.6-0.7\right.$ at $\sim 950$ ${ }^{\circ} \mathrm{C}$ ) where the $\mathrm{Si}$-andesite phenocryst assemblage is reproduced. However, as for the $200 \mathrm{MPa}$ $\boldsymbol{P E L}$ experiments, mismatch between experimental and natural phase compositions is 
observed. Orthopyroxenes in the domain above are all $<\mathrm{En}_{64}$ and none reaches the required $\mathrm{En}_{68-70}$ range. In the same way, none of the magnetites outside the stability field of amphibole and within the stability field of plagioclase have the required $\mathrm{Mt}_{74-76}$ composition (all are < $\left.\mathrm{Mt}_{70}\right)$. None of the $\boldsymbol{H U E}$ or $\boldsymbol{S A N}$ plagioclases outside the stability field of amphibole satisfy $A n_{55-60}\left(\right.$ all are $\left.<A n_{51}\right)$. Yet, the experimental En and Mt are too low to be applied directly to Si-andesite compositions because (1) they come from slightly too reduced experiments and (2) both the $\boldsymbol{S A N}$ and $\boldsymbol{H U E}$ starting compositions have lower Mg\# (respectively 0.22 and 0.24) than Cotopaxi $\mathrm{Si}$-andesites $\left(\mathrm{Mg} \#=0.31-0.32\right.$, down to 0.26 for the most $\mathrm{SiO}_{2}$-rich products; Fig. 2). Similarly, experimental An contents (mainly $\boldsymbol{S A N}$ samples) must be corrected upwards to account for the $\mathrm{Al}_{2} \mathrm{O}_{3}$-poor character of this particular starting composition. Although the corrections to be applied are difficult to evaluate rigorously, they are also all of limited importance ( $<10 \mathrm{~mol} \%$ for Mt, En and An). The important point is that they all strengthen the case for the $\sim 400 \mathrm{MPa}, T \sim 950^{\circ} \mathrm{C}, \sim \mathrm{NNO}+2$, and $X_{\mathrm{H} 2 \mathrm{Oin}} \sim 0.5-0.7$ as a possible crystallization domain for the Cotopaxi Si-andesites.

\subsection{Rhyolites}

\subsubsection{Selection of the experimental studies}

The selected phase-equilibrium studies include those performed on the 2008 Plinian eruption of Chaíten, Chile (CHAI; Castro and Dingwell, 2009), on a rhyolite (WL17; Waters and Lange, 2017), on the $\sim 3.6$ ka Minoan Plinian eruption of Santorini, Greece (MIN; Cadoux et al., 2014), on the Australian Wangrah granite (AB412; Klimm et al., 2003) and on the Brazilian Jamon granite (JAM; Dall'agnol et al., 1999). Fig. 2 shows that the $\boldsymbol{C H A I}$ composition (75 wt\% $\mathrm{SiO}_{2}$ ) is close to the most evolved Cotopaxi rhyolites, whereas WL17, $\boldsymbol{M I N}, \boldsymbol{A B 4 1 2}$, and $\boldsymbol{J A M}\left(72-73 \mathrm{wt} \% \mathrm{SiO}_{2}\right)$ approach the least evolved samples. In comparison with Cotopaxi, MIN is richer in $\mathrm{FeO}_{\mathrm{t}}$ (by $1 \mathrm{wt} \%$ ); the two granites $(\boldsymbol{A B 4 1 2}$ and $\boldsymbol{J A M}$ ) are poorer in $\mathrm{Al}_{2} \mathrm{O}_{3}$ (by $2 \mathrm{wt} \%$ ) and richer in $\mathrm{FeO}_{\mathrm{t}}$ (by $2 \mathrm{wt} \%$ ).

Using experimental phase relations and compositions from those studies, we aim at defining conditions that simultaneously yield crystallization of $\leq 5 \%$ crystals of plagioclase $\left(\mathrm{An}_{30-35)}\right.$, biotite (with $\mathrm{Mg \#}$ of $\left.0.5-0.7, \mathrm{Bt}_{0.5-0.7}\right), \mathrm{Mt}_{84}, \mathrm{Ilm}_{77}$, and quartz in a residual liquid with 76-78 wt $\mathrm{SiO}_{2}$. Amphibole is not part of the stable phase assemblage in Cotopaxi rhyolites.

\subsubsection{Pressure of $200 \mathrm{MPa}$ and below / $\geq 7 \mathrm{~km}$ depth}


The $\boldsymbol{C H A I}$ experiments were performed at $P$ from 50 to $200 \mathrm{MPa}, T$ from 750 to $950{ }^{\circ} \mathrm{C}$ and a $f_{\mathrm{O} 2}$ of $\mathrm{NNO}+1$. Only plagioclases and a few orthopyroxenes from run products have been analyzed. The $\boldsymbol{W L 1 7}$ experiments were performed between 80 and $185 \mathrm{MPa}$, at 785 to $850{ }^{\circ} \mathrm{C}$ and a $f_{\mathrm{O} 2}$ close to the $\mathrm{NNO}$ buffer. $\mathrm{H}_{2} \mathrm{O}$-saturated conditions $\left(X_{\mathrm{H} 2 \mathrm{Oin}}=1\right)$ were imposed in both studies. Experimental results show that, below 175-200 $\mathrm{MPa}$ (depending on the rhyolite starting composition), orthopyroxene is present as a stable phase in a wide temperature range $\left(750-850{ }^{\circ} \mathrm{C}\right.$ ). Biotite, to be stable, requires temperatures $<\sim 775{ }^{\circ} \mathrm{C}$ (Fig. 10). Consequently, $175-200 \mathrm{MPa}$ (i.e. below $\sim 7 \mathrm{~km}$ below the summit) is too low a pressure for the crystallization of Cotopaxi rhyolites which lack orthopyroxene phenocrysts. The rhyolitic $\left(\mathrm{An}_{30-35}+\mathrm{Bt}+\mathrm{Mt}\right.$ ) natural phase assemblage is reproduced at $\sim 750{ }^{\circ} \mathrm{C}$ and $\sim 200 \mathrm{MPa}$, i.e., near the liquidus (Fig. 10), consistent with the low crystallinities $(<5 \mathrm{wt} \%)$ required. Quartz crystallizes at a lower pressure in both the CHAI and WLI7 experiments (Fig. 10) and this casts doubt on the significance of quartz phenocrysts in the Cotopaxi rhyolites. Note that MIN and $\boldsymbol{A B 4 1 2}$ (both with significant compositional differences with Cotopaxi rhyolites) crystallize amphibole at $T \geq 700{ }^{\circ} \mathrm{C}$ under $\mathrm{H}_{2} \mathrm{O}$-saturated conditions (SM6A).

Because the CHAI and WLI7 runs were all $\mathrm{H}_{2} \mathrm{O}$-saturated, the influence of the water concentration is evaluated from the $\boldsymbol{A B 4 1 2}$ and $\boldsymbol{M I N}$ results. The compiled phase diagram at 700-900 ${ }^{\circ} \mathrm{C}$ and $0<\Delta \mathrm{NNO}<+1$ (SM6A) shows that, under $\mathrm{H}_{2} \mathrm{O}$-undersaturated conditions, it is virtually impossible to have plagioclase and biotite crystallizing in low $(<5 \%)$ amounts without orthopyroxene (and also amphibole depending on the starting composition) being also present. Although obtained on rhyolite compositions different from Cotopaxi, these results tend to restrict Cotopaxi rhyolite crystallization to conditions very close to $\mathrm{H}_{2} \mathrm{O}$-saturation.

\subsubsection{Pressure of $300 \mathrm{MPa} / 11 \mathrm{~km}$ depth}

The phase diagram for the $\boldsymbol{J A M}$ composition at 700 to $900{ }^{\circ} \mathrm{C}$ and $\mathrm{NNO}+2.5$ shows that, to achieve low crystallinities $(<\sim 5 \%)$ without amphibole being stable, near-liquidus $\mathrm{H}_{2} \mathrm{O}-$ rich $\left(X_{\mathrm{H} 2 \mathrm{Oin}}>0.9\right)$ conditions and low temperatures $\left(T \sim 700^{\circ} \mathrm{C}\right)$ are necessary (SM6B). In this very restricted domain of the phase diagram, saturation curves for plagioclase, quartz, biotite, K-feldspar and titanite all converge. The phenocryst assemblage of Cotopaxi rhyolites includes neither K-feldspar, titanite nor amphibole, which suggests that crystallization in this domain is inappropriate. In addition, the temperature required $\left(\sim 700{ }^{\circ} \mathrm{C}\right)$ is lower than the range inferred from $\mathrm{Fe}-\mathrm{Ti}$ oxides $\left(728-774^{\circ} \mathrm{C}\right)$. We conclude that $300 \mathrm{MPa}$ represents an upper limit for the crystallization of Cotopaxi rhyolites. 


\subsubsection{Pressure of $400 \mathrm{MPa} / 16 \mathrm{~km}$ depth}

Only the $M I N$ composition has been crystallized at this pressure, at $850-900{ }^{\circ} \mathrm{C}$, NNO -2 and for $X_{\mathrm{H} 2 \mathrm{Oin}}$ between 1 and 0.6. Results stress the absence of biotite and the ubiquitous presence of pyroxene in experimental phase assemblages, which is clearly inconsistent with natural rhyolites. However, these data are for a temperature range which is too high for the Cotopaxi rhyolites, on the basis of Fe-Ti oxide thermometry and CHAI and WLI7 rhyolite phase relations. Therefore, with the available data, we cannot strictly rule out the possibility of rhyolite crystallization at $400 \mathrm{MPa}$.

\section{Discussion}

\subsection{Storage conditions of the Cotopaxi rhyolitic magmas}

According to the natural samples and phase-equilibrium studies, the Peñas Blancas and Fseries rhyolites possibly crystallized around $750^{\circ} \mathrm{C},+1<\Delta \mathrm{NNO}<+2$, at $\sim 200-300 \mathrm{MPa}$ (depth $\sim 7-11 \mathrm{~km}$ ) and near $\mathrm{H}_{2} \mathrm{O}$ saturation ( 6-8 wt\% after Newman and Lowerstern, 2002; Fig. 11). The presence of sparse amphiboles and pyroxenes inherited from dacitic to andesitic magma raises the question of the origin of plagioclase and biotite in the rhyolites. Yet, none of the andesite phase diagrams show crystallization of $\mathrm{An}_{30-35}$ or biotite in the $P-T$ range of $100-400$ $\mathrm{MPa}$ and $850-1050{ }^{\circ} \mathrm{C}$, supporting the idea that plagioclase and biotite are cognate crystals of the rhyolitic magma.

The ignimbrites of Colorado Canyon Series and of Chalupas Caldera are more potassic by nearly $2 \mathrm{wt} \% \mathrm{~K}_{2} \mathrm{O}$ with respect to the Cotopaxi rhyolites and, thus, are comparable to the Wangrah_AB421 granite (Klimm et al., 2008; Fig. 2). The $\boldsymbol{A B 4 2 1} 200 \mathrm{MPa}$ and NNO phase diagram suggests that the Canyon Colorado Series and Chalupas Caldera ignimbrites could have crystallized at $200 \mathrm{MPa}, \sim 700{ }^{\circ} \mathrm{C}$ with a $\mathrm{H}_{2} \mathrm{O}$ content close to saturation ( $\left.\sim 6.5 \mathrm{wt} \%\right)$, i.e., under conditions only slightly different (colder) than those inferred for the Cotopaxi rhyolites.

\subsection{Storage conditions of the Cotopaxi andesitic magmas}

The andesites define a continuous group from $\sim 57 \mathrm{wt} \% \mathrm{SiO}_{2}$ and $\sim \mathrm{wt} \% \mathrm{MgO}(\mathrm{Mg}-$ andesites) to $\sim 62 \mathrm{wt} \% \mathrm{SiO}_{2}$ and $\sim 2 \mathrm{wt} \% \mathrm{MgO}$ (Si-andesites; Fig. 2), the least evolved magmas erupting as strombolian type (lava flows and scoria ballistics) and the most evolved 
more explosively as pumiceous pyroclastic flows and fallouts. The continuity in the wholerock data, compositional similarity between $\mathrm{Mg}$-andesite matrix glasses and bulk rock Siandesites (Fig. 5) plus isotopic constraints (Garrison et al. (2006) suggest that the two andesite types are comagmatic and belong to the same differentiation trend.

The Mg-andesite experiments that best reproduce the Cotopaxi phase assemblage and compositions, i.e. $975-1000{ }^{\circ} \mathrm{C}$ and $X_{\mathrm{H} 2 \mathrm{Oin}}=0.5-0.7$, do not allow the discrimination between a $P$ of either 200 or $400 \mathrm{MPa}$ (except for a slight difference in clinopyroxene En content, as also noted for the TUN experiments; Andújar et al, 2017). Accordingly, we propose that Cotopaxi Mg-andesites crystallized at $T$ of $\sim 1000{ }^{\circ} \mathrm{C}, \Delta \mathrm{NNO}+2, X_{\mathrm{H} 2 \mathrm{Oin}} \sim 0.5-0.7$, and $P$ from 200 to $\geq 400 \mathrm{MPa}$ (i.e., 7 to $\geq 16 \mathrm{~km}$ depth). The $\mathrm{H}_{2} \mathrm{O}$ contents of $4.5-6.0_{ \pm 0.7} \mathrm{wt} \%$ measured in the $\boldsymbol{T U N}$ charges at $400 \mathrm{MPa}, \Delta \mathrm{NNO}+2, X_{\mathrm{H} 2 \mathrm{Oin}}$ of 0.5 to 0.7 (Andújar et al, 2017) are in agreement within error with the $\mathrm{H}_{2} \mathrm{O}$-richest glass inclusions showing $\sim 3.5_{ \pm 0.7} \mathrm{wt} \%$ only for the lowest contents. However, the analyzed glass inclusions were trapped in pyroxenes that could have crystallized as well at higher depths or from a more mafic magma, which if necessary does not require a perfect $\mathrm{H}_{2} \mathrm{O}$-content matching between the glass inclusions and the selected experimental glasses. Cooling the Mg-andesite produces $\mathrm{Si}$-andesites. Based on experiments that best reproduce the Cotopaxi phase assemblage and compositions, crystallization temperatures close to $950{ }^{\circ} \mathrm{C}$ are suggested, but do not permit constraining pressure between 200 and $\geq 400 \mathrm{MPa}$.

The Si-andesitic (61-62 wt $\% \mathrm{SiO}_{2}$ and 2-3 wt\% $\mathrm{MgO}$ ) lavas of Morurcu, a Cotopaxi satellite vent whose deposit stratigraphically marks the transition between Cotopaxi I and IIA sequences, contain amphibole, together with plagioclase and scarce clinopyroxenes (Garrison et al., 2011). Thus, the Morurcu magmas could have crystallized in the 200-400 MPa $P$ range, $\Delta \mathrm{NNO}+2$, at slightly lower $T\left(<930{ }^{\circ} \mathrm{C}\right)$ and higher $\mathrm{H}_{2} \mathrm{O}$ contents $(>6 \mathrm{wt} \%)$, than the Cotopaxi Si-andesites, in order to stabilize amphibole (Fig. 9). However, further investigation of the phase compositions is necessary to refine the crystallization conditions of the Morurcu lavas.

The contrasted eruptive dynamics of Cotopaxi $\mathrm{Mg}$ - and $\mathrm{Si}$-andesites thus rely on composition and temperature differences rather than differences in $\mathrm{H}_{2} \mathrm{O}$ contents. Increasing temperature and magnesium content (silicate melt network-modifier) while decreasing $\mathrm{SiO}_{2}$ content (silicate melt network-former), acts to decrease melt viscosity (Mysen et al., 1982), so that $\mathrm{Mg}$-andesites $\left(\sim 1000{ }^{\circ} \mathrm{C}, 3-5 \mathrm{wt} \% \mathrm{MgO}, 57-60 \mathrm{wt} \% \mathrm{SiO}_{2}\right)$ are less viscous than $\mathrm{Si}$ andesites $\left(\sim 950{ }^{\circ} \mathrm{C}, 2-3 \mathrm{wt} \% \mathrm{MgO}, 60-62 \mathrm{wt} \% \mathrm{SiO}_{2}\right)$. Consequently, the $\mathrm{Mg}$-andesites erupt 
mostly effusively, as lava or scoria-rich flows, whereas Si-andesites erupt explosively, as siliceous pyroclastic flows and ash fallouts.

\subsection{Petrological relationships between the andesitic and rhyolitic magmas}

Based on isotopic and trace-element data, Garrison et al. (2006, 2011) suggested that crustal contamination is predominant over source contamination in the Cotopaxi magmatic system and that magma evolution is consistent with a crustal assimilation-fractional crystallization process. Their crystal fractionation modelling consistently reproduces the differentiation trend from the least evolved andesites to the rhyolites, starting from an assemblage of amphibole, plagioclase, two pyroxenes, and olivine. Remnants of this primitive magma are likely provided by some highly-calcic plagioclase cores, such as the $\mathrm{An}_{78-88}$ profile in Fig. 4 (Garrison et al., 2011). Therefore, these authors proposed rhyolite formation by melt segregation from the andesitic mush, with the segregated melt composition spanning $\mathrm{SiO}_{2}$ contents from 62 to $82 \mathrm{wt} \%$. In the present study, matrix glasses with $\mathrm{SiO}_{2}$ contents $>74 \mathrm{wt} \%$ in Garrison et al. (2011) have been excluded on the criterion that these residual glasses come from microlite-rich andesitic lavas that experienced cooling at sub-surface conditions (i.e., post-storage modifications). This leaves us with matrix glasses in microlite-free or -poor andesitic pumice or scoria ranging from 62 to $71 \mathrm{wt} \% \mathrm{SiO}_{2}$ (Fig. 5 and Pistolesi et al., 2011). We note that $\sim 71 \mathrm{wt} \% \mathrm{SiO}_{2}$ is the composition of glasses in $\mathrm{Si}$-andesite experiments at $\sim 930$ ${ }^{\circ} \mathrm{C}$ and $400 \mathrm{MPa}$ (Fig 9). Therefore, natural and experimental glass compositions concur to corroborate the proposition (Garrison et al. 2006, 2011) that fractional crystallization is the main petrogenetic process in the magmatic evolution from Cotopaxi Si-andesites to rhyolites. This conclusion does not exclude sporadic intervention of other mechanisms such as magma mixing, to account for the presence of some inherited crystals in rhyolites.

\subsection{Magma chamber model}

There is limited evidence of intermingling between andesites and rhyolites over the period of time of Cotopaxi activity, such as few andesitic enclaves in rhyolites (Hall and Mothes, 2008) and rare pyroxenes (Garrison et al., 2011) and amphiboles inherited from andesitesdacites in rhyolites. Most mingled samples comprise andesite end-members (e.g. 58 and $\sim 63$ wt $\% \mathrm{SiO}_{2}$ such as in the $1130 \mathrm{AD}$ deposit; Pistolesi et al., 2011), but do not involve rhyolites. This suggests that the reservoirs either do not activate at the same time or cannot 
communicate physically (so that ascending andesite would not necessarily enter the rhyolitic reservoir). The latter alternative seems unlikely since transport of the rhyolitic residual melt from the andesite storage region must have necessarily taken place to feed the upper rhyolitic reservoir. There is also evidence for a stationary eruptive conduit over the known eruptive history of the volcano (Hall and Mothes, 2008). Therefore, the former alternative, with both reservoirs not being activated at the same time, is the one preferred here. This implies fluctuations in deep magma fluxes and/or changes in tectonic setting to account for the activation of either reservoir. In particular, the historical period is characterized by spurting andesitic eruptions (frequent and of small to moderate volumes) that may result from frequent magma recharge events that do not allow time for advanced magma differentiation and physical extraction of the residual melt. Such frequent eruptions may be temporarily favored by a tectonic context facilitating andesite ascent from $\sim 16 \mathrm{~km}$ below the summit (Fig. 11). In contrast, the early edification stage of Cotopaxi was characterized by large eruptions of mostly rhyolitic magma suggesting that the parental andesitic magma had little opportunity to reach the surface at the time (andesites interbedded in the rhyolitic stratigraphy are scarce). This may result from low or sparse fluxes of magmas recharging the deep reservoir and allowing rhyolitic melt extraction and storage from shallower $(\sim 711 \mathrm{~km})$ depths (Fig. 11). Thus, cyclic temporal changes in deep magma flux and tectonic setting controlled the possibility of rhyolitic magma extraction and the longevity of the shallow rhyolitic storage reservoir.

\subsection{Present-day plumbing system}

In 2001-2002, 2009, and 2015, Cotopaxi showed noticeable episodes of increasing volcano-tectonic (VT) and long (LP) to very long period (VLP) seismic signals. Classically, VT events are related to fracturing of the medium whereas LP-VLP events are related to fluid movement, either magmatic or hydrothermal. In 2001-2002, VLP signals, located at 3-4 km depth, were observed in the NE flank (Molina et al, 2008). The same kind of VLP signals were described in 2009 by Kumagai et al. (2010) and in 2015 by Arias (2016), being located at $2 \mathrm{~km}$ and 2-4 $\mathrm{km}$ depth towards the E flank and slightly towards the $\mathrm{N}$ of the summit, respectively. The LP signals were interpreted as the resonance of the crack above the magmatic system (Molina et al., 2008) whereas VLP signals may result from the volumetric expansion of the crack due to magma intrusion (Molina et al., 2008; Kumagai et al., 2010; Arias, 2016). By inversion of ground deformation data during the 2001-2002 seismic crises, 
Hickey et al. (2015) located a magmatic source at $4-5 \mathrm{~km}$ depth towards the SW flank and reconciled this source of recharge with the seismicity located in the NE flank (Molina et al., 2008) as resulting from fluid migration from SW to NE along fault systems. A magmatic intrusion at $\sim 4-5 \mathrm{~km}$ is shallower than estimated here for the rhyolitic reservoir $(\sim 7-11 \mathrm{~km})$. However, the presence of pyroxene phenocrysts and dacitic matrix glasses in the 2015 juvenile ash clasts (Gaunt et al., 2016) corroborates the andesitic composition of the magma. Mild deformation on the GPS network recorded through early 2016 and several distal stations showed convincing patterns of outward deformation as a response to a possible deep source over $15 \mathrm{~km}$ deep (Mothes et al., 2017). Such a magmatic source location fully agrees with the depth estimates obtained from experimental petrology for the andesites (Fig. 11).

This leaves an important outstanding question concerning the present existence of a shallow rhyolitic reservoir at $\sim 4-11 \mathrm{~km}$ below the summit. Indeed, whether rhyolites or $\mathrm{Mg}$ andesites are about to erupt is fraught with consequences regarding risk assessment, since rhyolites have so far erupted much more explosively and voluminously than did andesites. Experimental petrology suggests that rhyolites and andesites may both be stored at shallow depths (i.e., 7-11 km; andesites are potentially stored over much larger - deeper - depth), so that geophysical (seismic and geodetic) data alone may not discriminate between magma and thus eruption - type. Geochemical monitoring such as analyses of emitted gases and juvenile ashes may provide additional data to predict which reservoir is being activated. For instance, the andesitic nature of the 2015 juvenile ashes makes it likely the present reactivation of the andesitic reservoir, thus ruling out rhyolitic eruptions in a near future.

\section{Conclusions}

Preexisting phase-equilibrium experiments have been used successfully to interpret Cotopaxi eruption products in terms of magma storage conditions. Although probably not as precise as a set of experiments specifically designed for Cotopaxi volcano, the present approach has the advantage of providing valuable information within a short time in case of volcano reactivation. Based on this approach, we propose that Cotopaxi Mg-andesites (57-60 $\mathrm{wt} \% \mathrm{SiO}_{2}, 3-5 \mathrm{wt} \% \mathrm{MgO}, \sim 4.5-6.0_{ \pm 0.7} \mathrm{wt} \% \mathrm{H}_{2} \mathrm{O}$ in melt) are stored between 200 and $\geq 400$ $\mathrm{MPa}\left(\sim 7\right.$ to $\geq 16 \mathrm{~km}$ below the summit), $\sim 1000{ }^{\circ} \mathrm{C}$ and $\sim \mathrm{NNO}+2$. Cooling of the $\mathrm{Mg}$ andesites by $\sim 50{ }^{\circ} \mathrm{C}$ produces the $\mathrm{Si}$-andesites (60-62 $\mathrm{wt} \% \mathrm{SiO}_{2} ; 2-3 \mathrm{wt} \% \mathrm{MgO}$ ). Extraction of the residual liquid from $\mathrm{Si}$-andesite crystallization produces the rhyolitic magma ( $\sim 6-8 \mathrm{wt} \%$ $\mathrm{H}_{2} \mathrm{O}$ in melt) stored at $\sim 200-300 \mathrm{MPa}\left(\sim 7-11 \mathrm{~km}\right.$ below the summit), $\sim 750{ }^{\circ} \mathrm{C}$ and $\mathrm{NNO}+2$. 
The contrasted eruptive dynamics of Cotopaxi is thus the consequence of different magma compositions and temperatures: the hot $\mathrm{Mg}$-rich andesites erupt effusively as lava or scoriarich flows, the slightly cooler Si-rich andesites erupt explosively as siliceous pyroclastic flows and ash fallouts, and the rhyolites generate highly explosive pumice fallouts and flows. The Mg-rich andesitic reservoir seems to be active at present, being likely recharged by magma pulses of deep origin. However, sparser or lower deep magma fluxes would allow more time for magma differentiation and residual melt extraction, which could reactivate the shallow rhyolitic reservoir.

\section{ACKNOWLEDGMENTS}

We would like to thank I. Di Carlo for help with the SEM analyses. This work benefitted from the financial support of the European FP7_VUELCO project (J. Gottsmann, PI) and Prometeo program from Ecuador (I. Molina, PI).

\section{REFERENCES}

Andújar, J., Scaillet, B., Pichavant, M., \& Druitt, T. H., 2016. Generation Conditions of Dacite and Rhyodacite via the Crystallization of an Andesitic Magma. Implications for the Plumbing System at Santorini (Greece) and the Origin of Tholeiitic or Calc-alkaline Differentiation Trends in Arc Magmas. J. Petrol. 57(10), 1887-1920.

Andújar, J., Martel, C., Pichavant, M., Samaniego, P., Scaillet, B., Molina, I., 2017. Structure of the plumbing system at Tungurahua volcano, Ecuador: Insights from phase equilibrium experiments on July-August 2006 eruption products. J. Petrol. 58(7), 1249-1278.

Araujo, S., 2016. Travel time tomography of the crust and the mantel beneath Ecuador from data of the national seismic network. PhD thesis, University of Grenoble Alpes, France.

Arias, G., 2016. Estudio de las señales sísmicas de muy largo periodo del Volcán Cotopaxi. $\mathrm{PhD}$ thesis, Escuela Politécnica National, Ecuador.

Bacon, C.R., Hirschmann, M.M., 1988. Mg/Mn partitioning as a test for equilibrium between coexisting Fe-Ti oxides. Am. Mineral. 73, 57-61.

Bernard, B., Battaglia, J., Proaño, A., Hidalgo, S., Vásconez, F., Hernandez, S., Ruiz, M., 2016. Relationship between volcanic ash fallouts and seismic tremor: quantitative assessment of the 2015 eruptive period at Cotopaxi volcano, Ecuador. Bull. Volcanol. 78, 80-91. 
Botcharnikov, R.E., Holtz, F., Almeev, R.R., Sato, H., Behrens, H., 2008. Storage conditions and evolution of andesitic magma prior to the 1991-95 eruption of Unzen volcano: Constraints from natural samples and phase equilibria experiments. J. Volcanol. Geotherm. Res. 175, 168-180.

Cadoux, A., Scaillet, B., Druitt, T.H., Deloule, E., 2014. Magma Storage Conditions of Large Plinian Eruptions of Santorini Volcano (Greece). J. Petrol. 55, 1129-1171.

Castro, J.M., Dingwell, D.B., 2009. Rapid ascent of rhyolitic magma at Chaiten volcano, Chile. Nature 461, 780-784.

Dall'agnol, R., Scaillet, B., Pichavant, M., 1999. An experimental study of a lower Proterozoic A-type granite from the Eastern Amazonian Craton, Brazil. J. Petrology 40, 1673-1698.

Devine, J.D., Gardner, J.E., Brack, H.P., Layne, G.D., Rutherford, M.J., 1995. Comparison of microanalytical methods for estimating $\mathrm{H}_{2} \mathrm{O}$ contents of silicic volcanic glasses. Am. Mineral. 80, 319-328.

Feininger, T., Seguin, M.K., 1983. Simple Bouguer gravity anomaly field and the inferred crustal structure of continental Ecuador. Geology 11, 40-44.

Font, Y., Segovia, M., Vaca, S., Theunissen, T., 2013. Seismicity patterns along the Ecuadorian subduction zone: new constraints from earthquake location in a 3-D a priori velocity model. Geophys. J. Int. 193 (1), 263-286.

Garrison, J.M., Davidson, J.P., Hall, M., Mothes, P., 2011. Geochemistry and petrology of the most recent deposits from Cotopaxi volcano, northern volcanic zone, Ecuador. J. Petrol. $52,1641-1678$.

Garrison, J.M., Davidson, J.P., Reid, M., Turner, S.P., 2006. Source versus differentiation controls on U-series disequilibria: insignts from Cotopaxi Volcano, Ecuador. Earth Planet. Sci. Lett. 244, 548-565.

Gaunt, E., Bernard, B., Hidalgo, S., Proaño, A., Wright, H., Mothes, P., Criollo, E., Kueppers, U., 2016. Juvenile magma recognition and eruptive dynamics inferred from the analysis of ash time series: The 2015 reawakening of Cotopaxi volcano. J. Volcanol. Geotherm. Res. $328,134-146$.

Ghiorso, M.S., Sack, R.O., 1991. Fe-Ti oxide geothermometry: thermodynamic formulation and estimation of intensive variables in silicic magmas. Contrib. Mineral. and Petrol. 108, $485-510$

Hall, M., Mothes, P., 2008. The rhyolitic-andesitic eruptive history of Cotopaxi volcano, Ecuador. Bull. Volcanol. 70, 675-702. 
Hickey, J., Gottsmann, J., Mothes, P., 2015. Estimating volcanic deformation source parameters with a finite element inversion: the 2001-2002 unrest at Cotopaxi volcano, Ecuador. J. Geophys. Res., Solid Earth 120, 1473-1486.

Holland, T., Blundy, J.D., 1994. Non-ideal interactions in calcic amphiboles and their bearing on amphibole-plagioclase thermometry. Contrib. Mineral. Petrol. 116, 433-447.

Klimm, K., Holtz, F., Johannes, W., King, P.L., 2003. Fractionation of metaluminous A-type granites: an experimental study of the Wangrah Suite, Lachlan Fold Belt, Australia. Precamb. Res. 124, 327-341.

Klimm, K., Holtz, F., King, P.L., 2008. Fractionation vs. magma mixing in the Wangrah Suite A-type granites, Lachlan Fold Belt, Australia: Experimental constraints. Lithos 102, 415434.

Kumagai, H., Nakano, M., Maeda, T., Yepes, H., Palacios, P., Ruiz, M., Arrais, S., Vaca, M.,Molina, I., Yamashima, T., 2010. Broadband seismic monitoring of active volcanoes using deterministic and stochastic approaches. J. Geophys. Res. 115, B08303, doi:10.1029/2009JB006889

Martel, C., Pichavant, M., Holtz, F., Scaillet, B., Bourdier, J.-L., Traineau, H., 1999. Effect of $\mathrm{fO}_{2}$ and $\mathrm{H}_{2} \mathrm{O}$ on andesite phase relations between 2 and 4 kbar. J. Geophys. Res. 104, B12, 29453-29470.

Martel, C., Radadi Ali, A., Poussineau, S., Gourgaud, A., Pichavant, M., 2006. Basaltinherited microlites in silicic magmas: evidence from Mt. Pelée (Martinique, F.W.I.). Geology 34, 905-908.

Molina, I., Kumagai, H., Garcia-Aristizabal, A., Nakano, M., Mothes P., 2008. Source process of very-long-period events accompanying long-period signals at Cotopaxi Volcano, Ecuador. J. Volcanol. Geotherm. Res. 176, 119-133.

Mothes, P.A., Ruiz, M.C., Viracucha, E.G., Ramón, P.A., Hernández, S., Hidalgo, S., Bernard, B., Gaunt, E., Jarrín, P., Yepez, M., Espín, P.A. 2017. Geophysical footprints of Cotopaxi's unrest and minor eruptions in 2015: an opportunity to test scientific and community preparedness. Book Chapter in Advances in Volcanology, DOI 10.1007/11157_2017_10, License CC BY 4.0, Springer.

Mysen, B.O., Virgo, D., Seifert, F.A., 1982. The structure of silicate melts: implications for chemical and physical properties of natural magma. Rev. Geophys. Space Phys. 20, 353383.

Newman, S., Lowenstern, J.B., 2002. VOLATILECALC: A silicate melt- $\mathrm{H}_{2} \mathrm{O}-\mathrm{CO}_{2}$ solution model written in Visual Basic for excel. Comp. Geosci. 28, 5, 597-604. 
Parat, F., Holtz, F., Feig, S., 2008. Pre-eruptive Conditions of the Huerto Andesite (Fish Canyon System, SanJuanVolcanic Field, Colorado): Influence of Volatiles (C-O-H-S) on Phase Equilibria and Mineral Composition. J. Petrol. 49(5), 911-935.

Pichavant, M., Costa, F., Scaillet B., Martel, C., Poussineau, S., Burgisser, A., 2007. Equilibration scales in silicic to intermediate magmas - Implications for experimental studies. J. Petrol. 48, 1955-1972.

Pistolesi, M., Mauro, R., Cioni, R., Cashman, K.V., Rossoti, A., Aguilera, E., 2011. Physical volcanology of the post-twelfth-century activity at Cotopaxi volcano, Ecuador: behavior of an andesitic central volcano. GSA Bull. 123(5-6), 1193-1215.

Putirka, K., 2008. Thermometers and barometers for volcanic systems. Rev. Mineral. Geochem. 69, 61-120.

Rutherford, M.J., Sigurdsson, H., Carey, S., Davis, A., 1985. The May 18, 1980, eruption of Mount St. Helens 1. Melt composition and experimental phase equilibria. J. Geophys. Res. 90, $\mathrm{N}^{\circ} \mathrm{B} 4,2929-2947$.

Sauerzapf, U., Lattard, D., Burchard, M., Engelmann, R., 2008. The Titanomagnetite-Ilmenite Equilibrium: New Experimental Data and Thermo-oxybarometric Application to the Crystallization of Basic to Intermediate Rocks. J. Petrol. 49, 1161-1185.

Taboada, A. et al., 2000. Geodynamics of the northern Andes: Subductions and intracontinental deformation (Colombia). Tectonics 19, 787-813.

Waters, L.E., Lange, R.A., 2015. An updated calibration of the plagioclase-liquid hygrometerthermometer applicable to basalts through rhyolites. Am. Mineral. 100, 2172-2184.

Waters, L.E., Lange, R.A., 2017. An experimental study of ${ }^{\mathrm{Fe} 2+-\mathrm{Mg}_{\mathrm{D}}}$ between orthopyroxene and rhyolite: a strong dependence on $\mathrm{H}_{2} \mathrm{O}$ in the melt. Contrib. Mineral. Petrol. 172, $42 \mathrm{p}$.

\section{Figure captions}

Fig. 1. (A) Location map of Cotopaxi volcano in the Eastern Cordillera of the Northern Volcanic Zones of the Ecuadorian Andes (red stars are volcanoes) and (B) Simplified stratigraphy of the Cotopaxi deposits showing the andesitic and rhyolitic sequences in green and black, respectively, the approximated dense-rock-equivalent of emitted volumes, and ages; modified after Hall and Mothes (2008). 
Fig. 2. Cotopaxi bulk-rock compositions, compiled from Garrison et al. (2011) and Pistolesi et al. (2011). The blue crosses are bulk-rock starting materials of phase-equilibrium experiments: $\boldsymbol{U N Z}$ for the Unzen andesite in Botcharnikov et al. (2008), $\boldsymbol{T} \boldsymbol{U} \boldsymbol{N}$ for the Tungurahua andesite in Andújar et al. (2017), SAN for the Santorini andesite in Andújar et al. (2016), PEL for the Montagne Pelée andesite in Martel et al. (1999), HUE for the Huerto andesite in Parat et al. (2008), WL17 for the rhyolite in Waters and Lange (2017), $\boldsymbol{A B 4 1 2}$ et $\boldsymbol{A B 4 2 1}$ for the Wangrah granites in Klimm et al. (2003, 2008), JAM for the Jamon granite in Dall'agnol et al. (1999), MIN for the rhyolitic Minoan eruption in Cadoux et al. (2014), and $\boldsymbol{C H A I}$ for the Chaiten rhyolite in Castro and Dingwell (2009).

Fig. 3. Frequency histograms for the compositions of (A) plagioclase, (B) two pyroxenes, and (C) magnetite. Data from Garrison et al. (2011) and SM1.

Fig. 4. Plagioclase analytical profiles. The grey boxes give the chosen rim compositions for plagioclase in andesite and rhyolite.

Fig. 5. Compositions of the matrix glasses (MG) and glass inclusions (GI). F-Rhyolites, Old andesites, Recent Si-andesites from Garrison et al. (2011); 2015 ash clasts from Gaunt et al. (2016); Recent Mg-andesites from Garrison et al. (2011) and SM1. Whole-rock (WR) compositions are shown for comparison (as in Fig. 2). Note that the $\mathrm{Na}_{2} \mathrm{O}$ contents display high variations that may be partly attributed to the difficulty in analyzing alkalis using an electron microprobe.

Fig. 6. $\mathrm{H}_{2} \mathrm{O}$ contents measured in pyroxene-hosted glass inclusions from the 1877 eruption. The point labels give the mole contents in enstatite (En) and wollastonite (Wo) of the orthopyroxenes and clinopyroxenes, respectively.

Fig. 7. Amphibole compositions plotted as $\mathrm{Al}^{\mathrm{IV}}$ pfu versus (A) cation number in alkali (A) site and (B) $\mathrm{Mg}$ number $\left(\mathrm{Mg \#}=\mathrm{Mg} /\left(\mathrm{Mg}+\mathrm{Fe}_{\text {tot }}\right)\right.$, in moles); all compositions calculated with iron as $\mathrm{FeO}$ and on a $\mathrm{H}_{2} \mathrm{O}$-free 23-oxygen basis. Black dots are the amphiboles in the $\mathrm{F}$ series rhyolites from Garrison et al. (2011). Experimental amphiboles are from JAM granite (Dall'agnol et al., 1999), AB412 granite (Klimm et al., 2003), MIN rhyolite (Cadoux et al., 2014), SAN Si-andesite (Andújar et al., 2016), and TUN Mg-andesite (Andújar et al., 2017). 
Fig. 8. Mg-andesite $T-X_{\mathrm{H} 2 \mathrm{O} \text { in }}$ diagram showing the phase relationships for $\boldsymbol{T U N}$ experiments at NNO +2 and (A) $200 \mathrm{MPa}$ and (B) $400 \mathrm{MPa}$ (modified after Andújar et al., 2017). Abbreviations: $C p x$ for clinopyroxene, $O p x$ for orthopyroxene, $P l$ for plagioclase, $O l$ for olivine, $A m$ for amphibole, $M t$ for magnetite, $I l m$ for ilmenite. Point labels give the crystal proportions (in bracket) and phase compositions ( $A n$ for anorthite content in plagioclase, Wo for wollastonite content in clinopyroxene, $E n$ for enstatite content in orthopyroxene (or in clinopyroxene where linked to $W o$ ), Fo for forsterite content in olivine, $M t$ for magnetite and $\mathrm{Ilm}$ for ilmenite content in the Fe-Ti oxides, in mol\%; $A m$ gives the $\mathrm{Al}_{2} \mathrm{O}_{3}$ content in amphibole and $G l$ gives the $\mathrm{SiO}_{2}$ content in glass, in wt\%). The red dashed fields demark possible storage conditions for the Cotopaxi Mg-andesites.

Fig. 9. Si-andesite $T-X_{\mathrm{H} 2 \mathrm{O} i n}$ diagram showing the phase relationships at $400 \mathrm{MPa}$ for $\boldsymbol{P E L}$ experiments at $\mathrm{NNO}+1$ (modified after Martel et al., 1999), $\boldsymbol{H} \boldsymbol{E}$ experiments at NNO (modified after Parat et al., 2008), and $\boldsymbol{S A N}$ experiments at NNO +1.5 (modified after Andújar et al., 2016). Abbreviations and point labels as in Fig. 8. The red dashed field demarks possible storage conditions for the Cotopaxi Si-andesites.

Fig. 10. Rhyolite $P-T$ diagram showing the phase relationships at $P \leq 200 \mathrm{MPa}$, $0<\Delta \mathrm{NNO}<+1$, and $\mathrm{H}_{2} \mathrm{O}$ saturation for the $\boldsymbol{C H} \boldsymbol{H I}$ experiments (Castro and Dingwell, 2009; from their Supplementary Table 1) and the WL17 experiments (Waters and Lange, 2017). Abbreviations and point labels as in Fig. 8 (with $\boldsymbol{B} \boldsymbol{t}$ for biotite and $\boldsymbol{Q z}$ for quartz). The red dashed field demarks possible storage conditions for the Cotopaxi rhyolites.

Fig. 11. Schematic view of the magmatic plumbing system beneath Cotopaxi volcano. Left side: storage of the andesitic magmas at pressures $\geq 400 \mathrm{MPa}(\geq 16 \mathrm{~km}$ depth), about 1000 ${ }^{\circ} \mathrm{C}$, $\mathrm{NNO}+2$, and 4.5-6.0+0.7 $\mathrm{wt} \% \mathrm{H}_{2} \mathrm{O}$ dissolved in the melt in equilibrium with $\sim 30-40 \%$ phenocrysts of plagioclase, two pyroxenes, and Fe-Ti oxides. Should this Mg-rich andesite cool by $\sim 50{ }^{\circ} \mathrm{C}$, a silicic andesite is produced. Whereas the Mg-rich andesite erupts effusively (ballistics and lava-and-scoria flows), the more viscous silicic andesite erupts explosively (pyroclastic flows and ash falls). Right side: storage of the rhyolitic magma around $200 \mathrm{MPa}\left(\sim 7 \mathrm{~km}\right.$ depth), $750{ }^{\circ} \mathrm{C}$, $\mathrm{NNO}+2$, and $6 \mathrm{wt} \% \mathrm{H}_{2} \mathrm{O}$ dissolved in a nearly aphiric melt (less than $5 \%$ phenocrysts of plagioclase, biotite, and Fe-Ti oxides). The rhyolitic eruptions are highly explosive (Plinian falls and pumice flows). Although the 
andesitic and rhyolitic reservoirs are linked by a process of fractional crystallization, Cotopaxi eruptive history suggests reactivation of either reservoir, likely depending on magma flux variations during deep magma recharge. For instance, the recent andesitic eruptions could result from frequent magma recharges that do not provide time for andesite differentiation and rhyolitic melt extraction towards shallower depths. In contrast, past low or sparse fluxes of magma recharge have permitted the generation of rhyolitic magmas. 


\section{Highlights}

Storage conditions for rhyolitic and andesitic magmas at Cotopaxi volcano, Ecuador, are presented, based on preexisting phase-equilibrium experiments. The approach is meant to provide valuable information within a short time in case of volcano reactivation. We propose that Cotopaxi Mg-andesites (57-60 wt\% $\mathrm{SiO}_{2}, 3-5 \mathrm{wt} \% \mathrm{MgO}, \sim 4.5-6.0_{ \pm 0.7} \mathrm{wt} \% \mathrm{H}_{2} \mathrm{O}$ in melt) are stored between 200 and $\geq 400 \mathrm{MPa}\left(\sim 7\right.$ to $\geq 16 \mathrm{~km}$ below the summit), $\sim 1000{ }^{\circ} \mathrm{C}$ and $\sim \mathrm{NNO}+2$. Cooling of the $\mathrm{Mg}$-andesites by $\sim 50{ }^{\circ} \mathrm{C}$ produces the Si-andesites (60-62 wt\% $\mathrm{SiO}_{2} ; 2-3 \mathrm{wt} \% \mathrm{MgO}$ ). Extraction of the residual liquid from Si-andesite crystallization produces the rhyolitic magma $\left(\sim 6-8 \mathrm{wt} \% \mathrm{H}_{2} \mathrm{O}\right.$ in melt) stored at $\sim 200-300 \mathrm{MPa}(\sim 7-11 \mathrm{~km}$ below the summit), $\sim 750{ }^{\circ} \mathrm{C}$ and $\mathrm{NNO}+2$. The contrasted eruptive dynamics of Cotopaxi is thus the consequence of different magma compositions and temperatures: the hot $\mathrm{Mg}$-rich andesites erupt effusively as lava or scoria-rich flows, the slightly cooler Si-rich andesites erupt explosively as siliceous pyroclastic flows and ash fallouts, and the rhyolites generate highly explosive pumice fallouts and flows. The $\mathrm{Mg}$-rich andesitic reservoir seems to be active at present, being likely recharged by magma pulses of deep origin. However, sparser or lower deep magma fluxes would allow more time for magma differentiation and residual melt extraction, which could reactivate the shallow rhyolitic reservoir. 

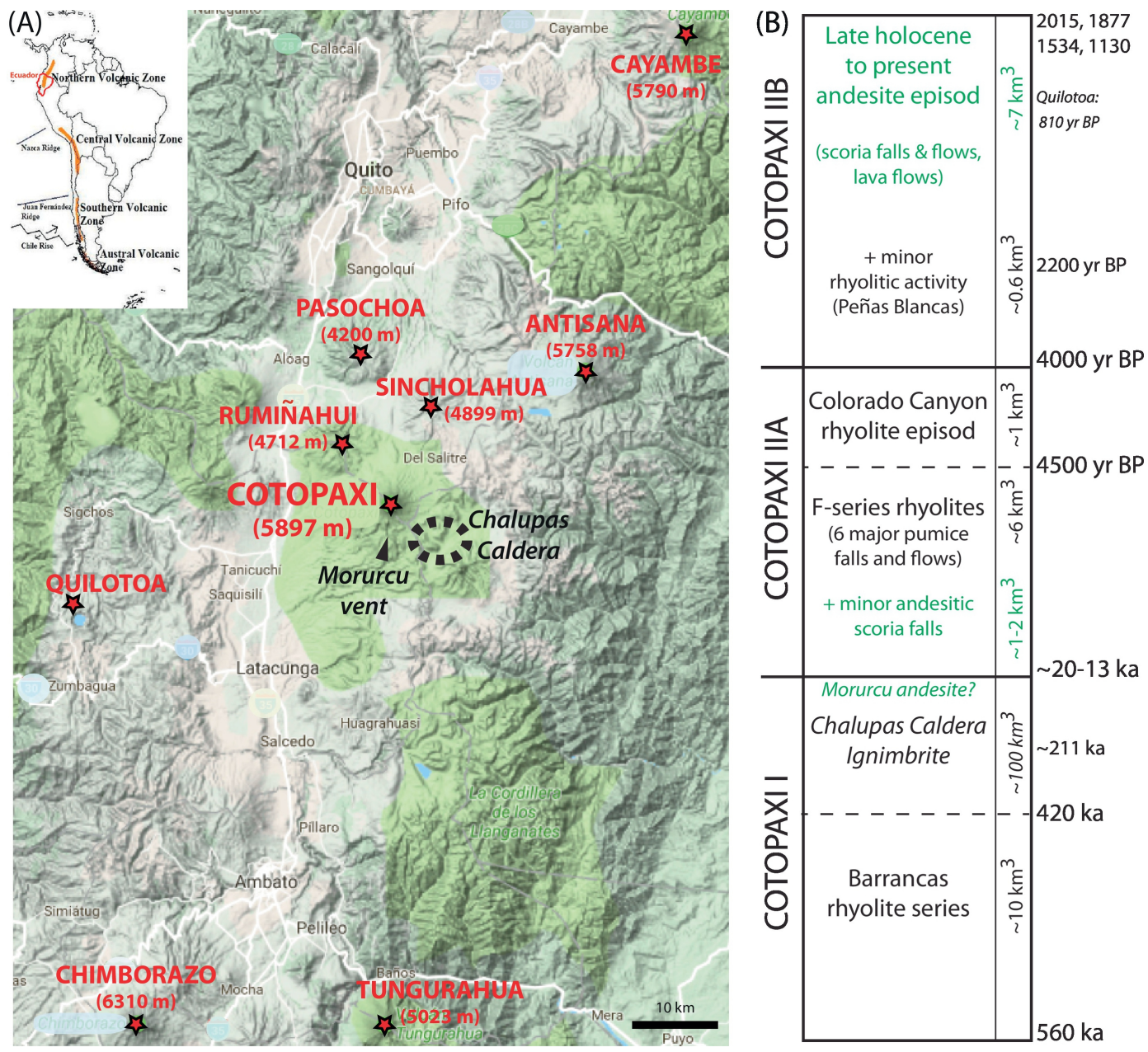

Figure 1 


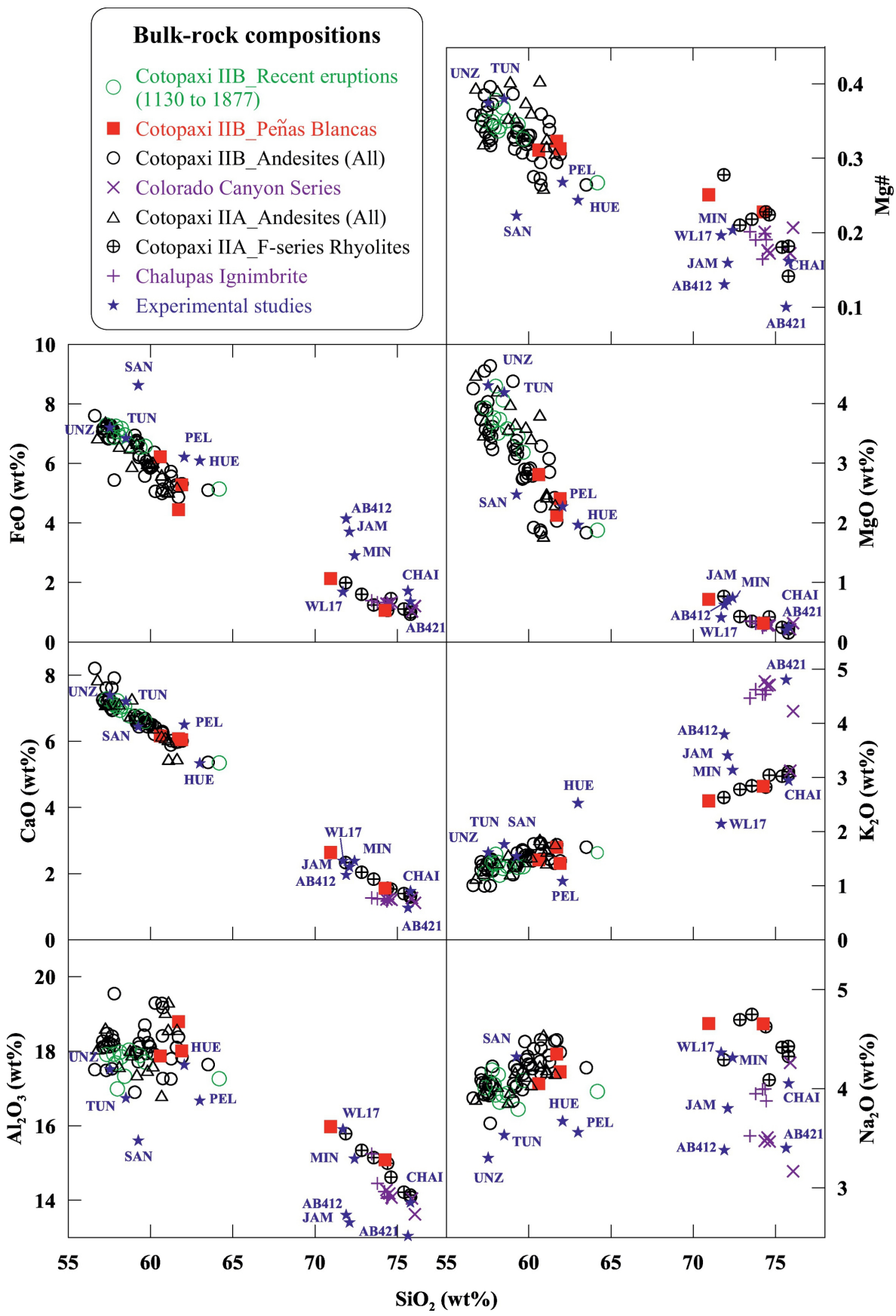




\section{(A) Plagioclase}

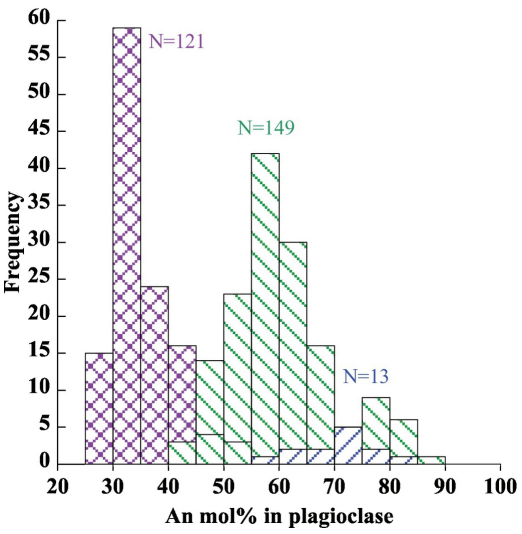

(B) Orthopyroxene

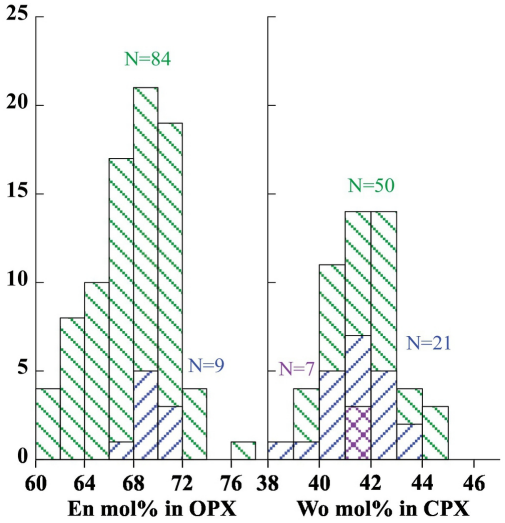

(C) Magnetite

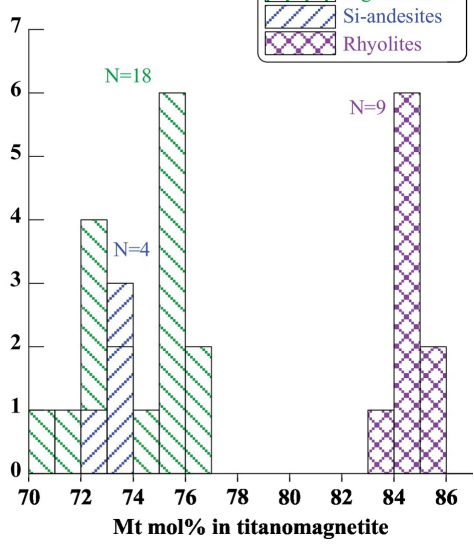

Figure 3 


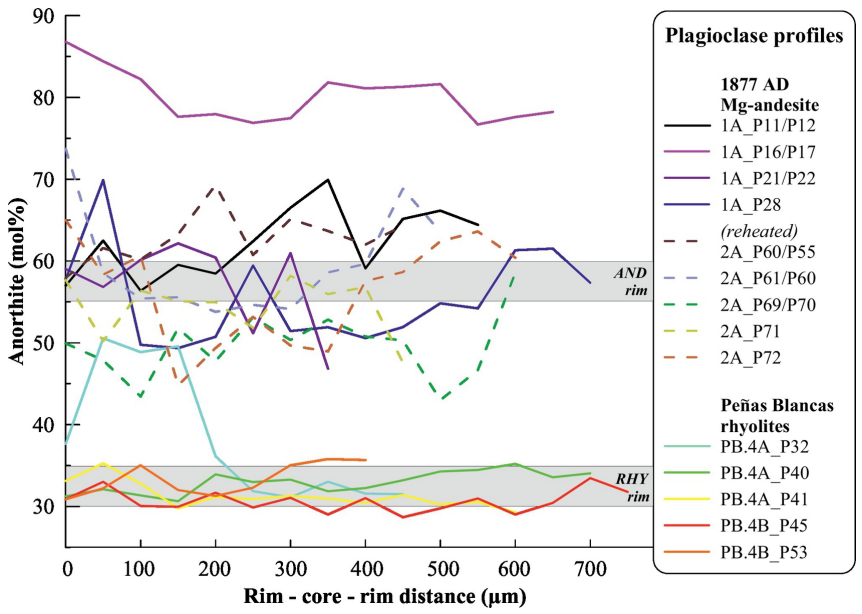

Figure 4 


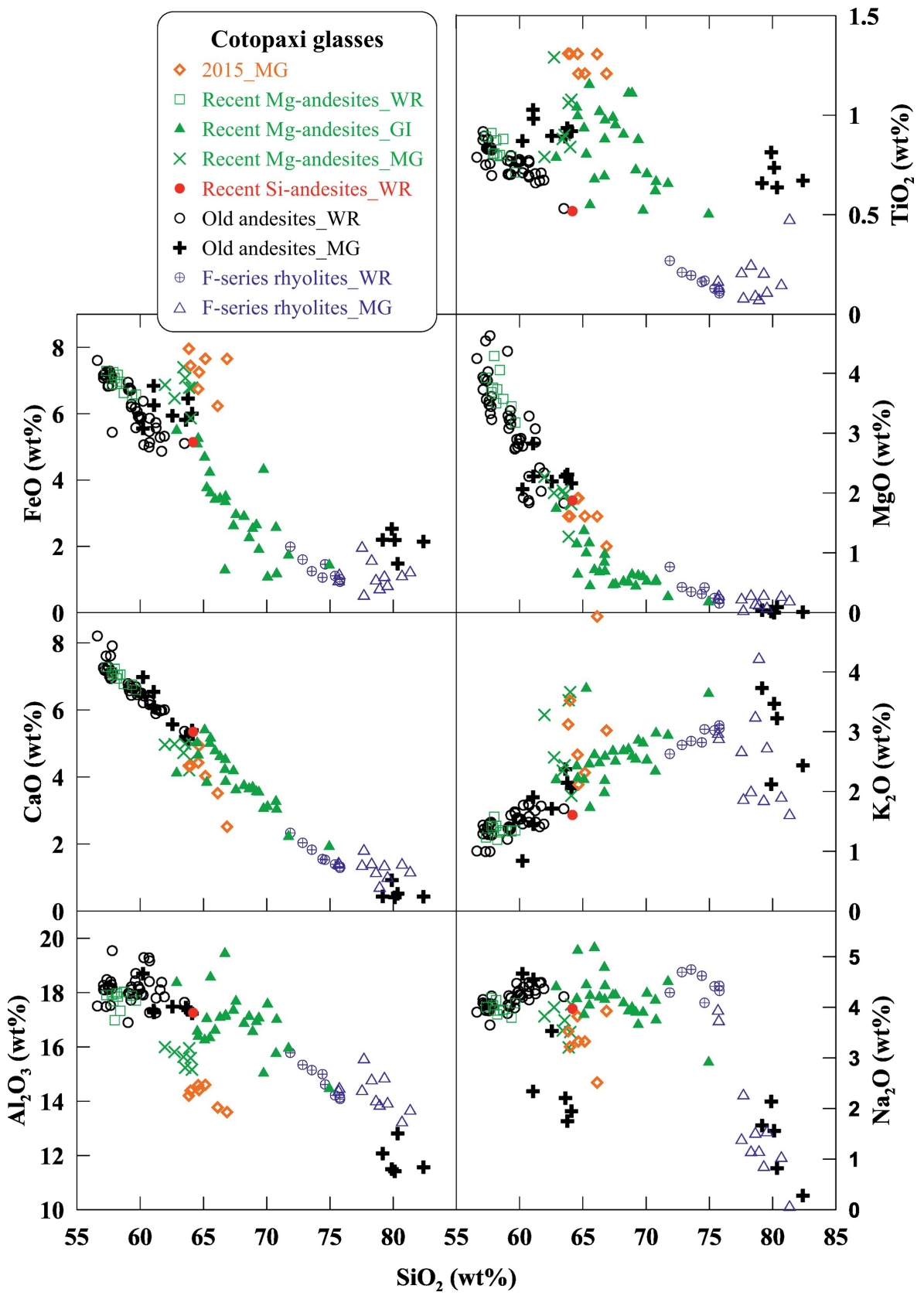




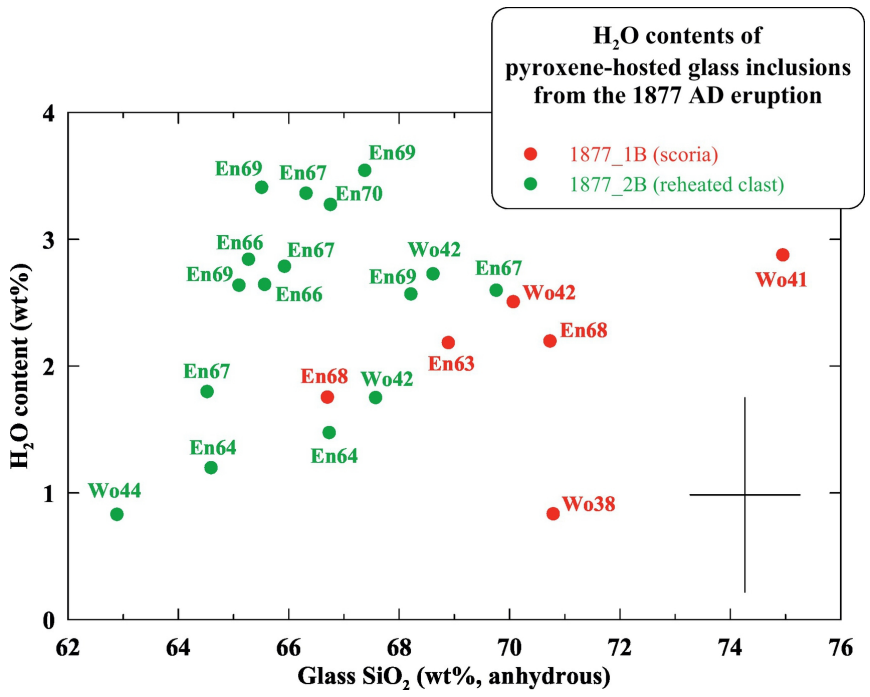

Figure 6 


\section{Amphibole}

- F4-series rhyolites (CTX19)

\section{Andesite experiments}

$\nabla \quad S A N, 400 \mathrm{MPa}, 925^{\circ} \mathrm{C}, \quad \mathrm{NNO}+1.5$ $\boldsymbol{T U N}, 200-400 \mathrm{MPa}, 950-1000^{\circ} \mathrm{C},+1<\Delta \mathrm{NNO}<+2$
Rhyolite experiments

$\diamond \quad$ MIN, $100-400 \mathrm{MPa}, 850^{\circ} \mathrm{C},-1<\Delta \mathrm{NNO}<+1$

+ JAM, $300 \mathrm{MPa}, 700-850^{\circ} \mathrm{C},-1.5<\Delta \mathrm{NNO}<+2.5$

○ $A B 412,200 \mathrm{MPa}, 750^{\circ} \mathrm{C}, \mathrm{NNO}$

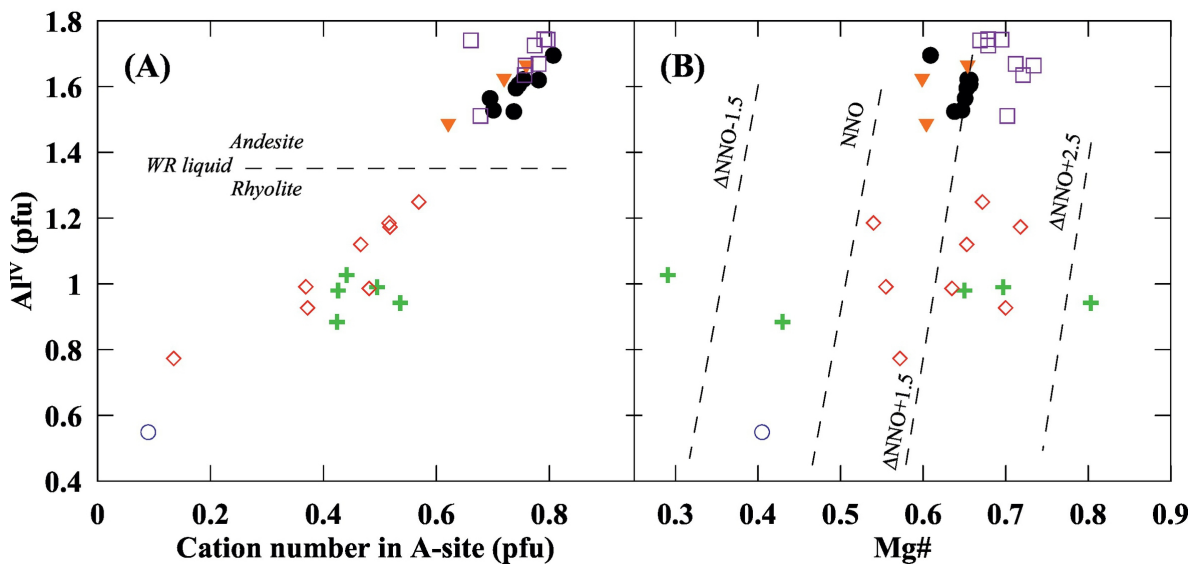

Figure 7 


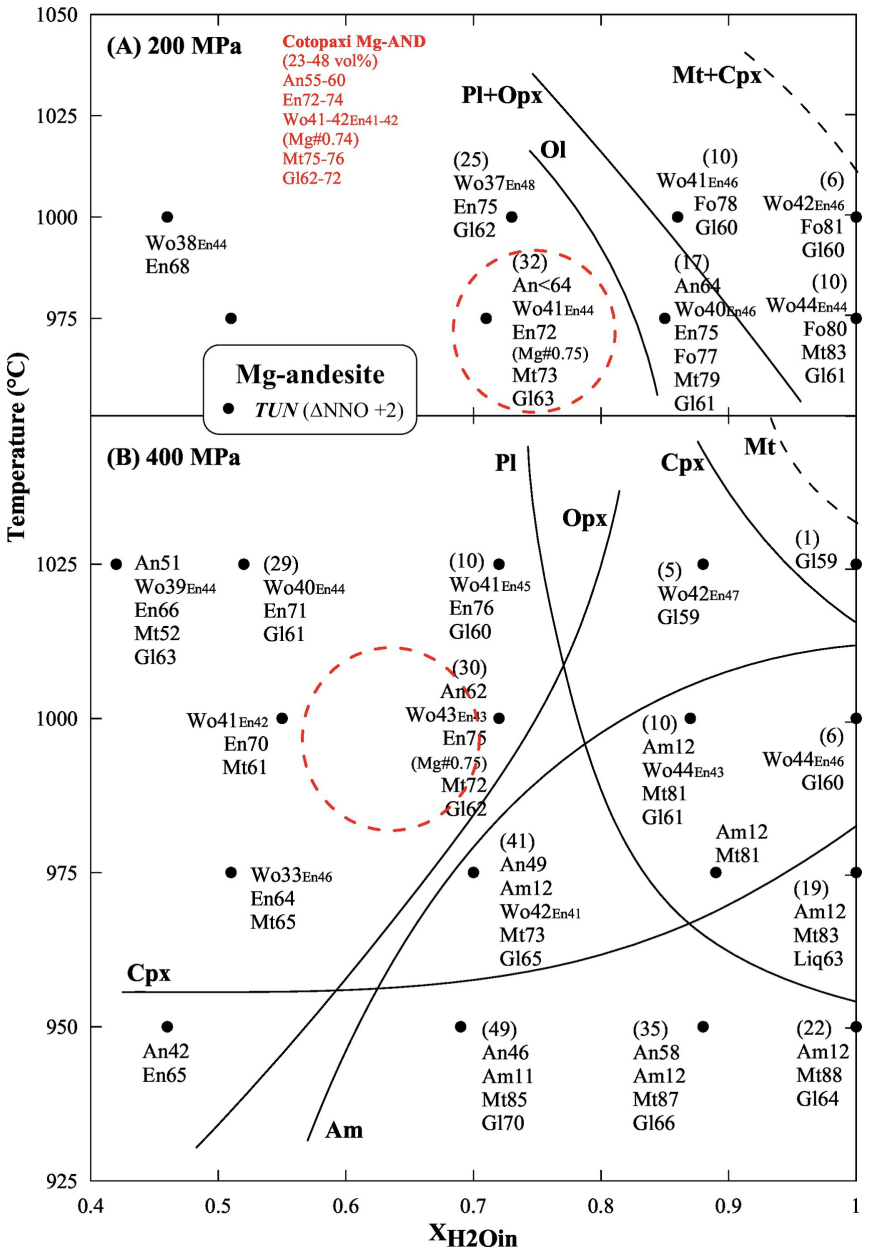




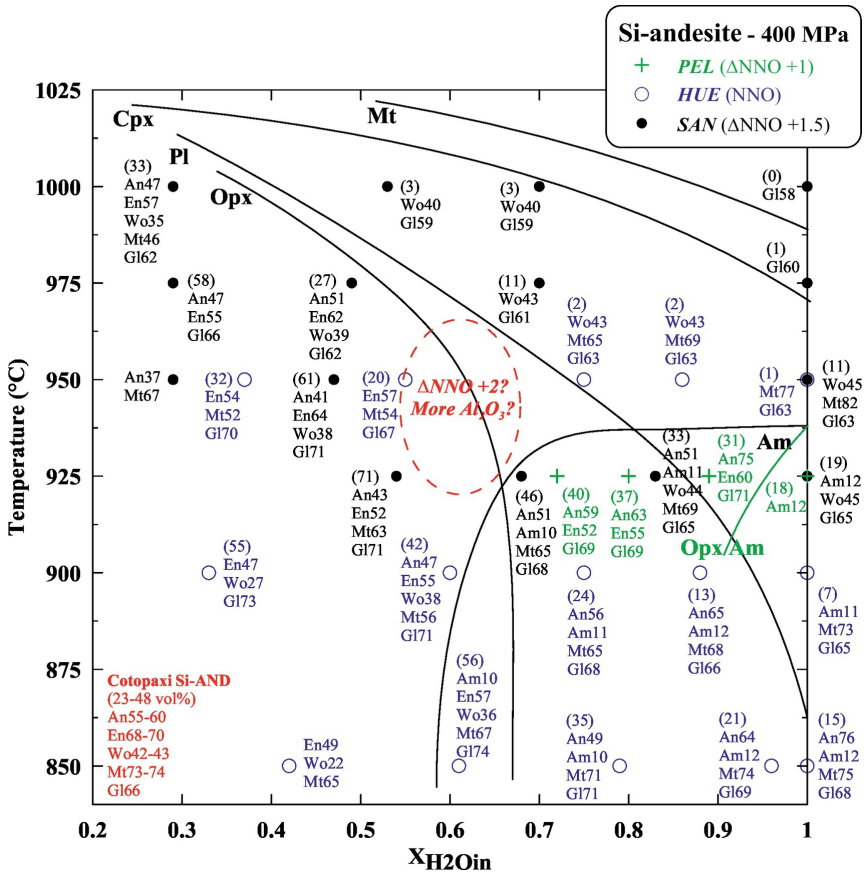

Figure 9 


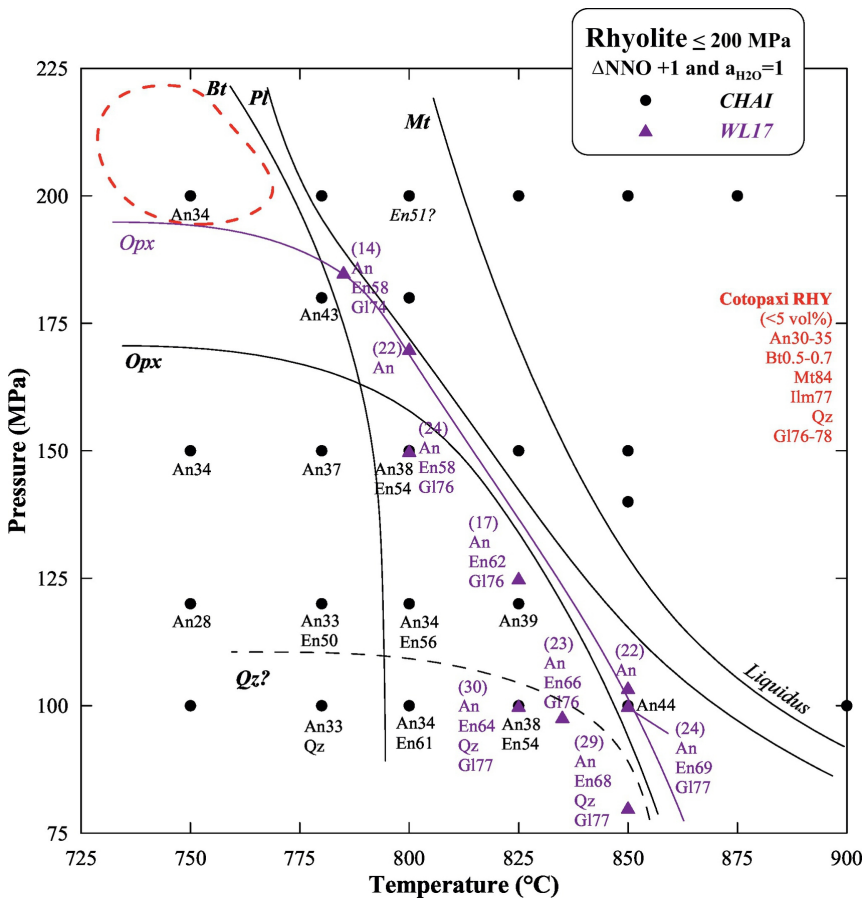

Figure 10 
Andesitic activity:

Ballistics and lava flows (Mg-andesite)

$$
\text { eg: } 2015,1877 A D
$$

Siliceous pyroclastic flows ( $\mathrm{Si}$-andesite)

eg: Peñas Blancas 2200 BP

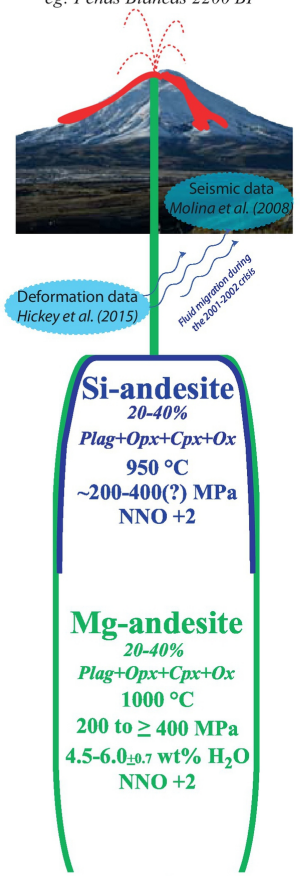

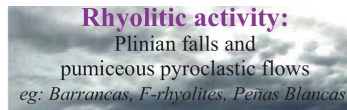

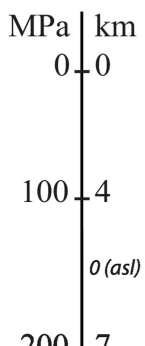

\section{Rhyolite}

$1-5 \%$ Plag $+B t+O x$

$750{ }^{\circ} \mathrm{C}-\sim 200-300 \mathrm{MPa}$

$\sim 6-8 \mathrm{wt} \% \mathrm{H}_{2} \mathrm{O}$

$\triangle \mathrm{NNO}+2$
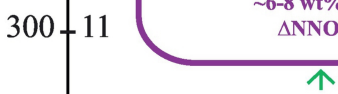

\section{Differentiation by fractional crystallization of the andesite}
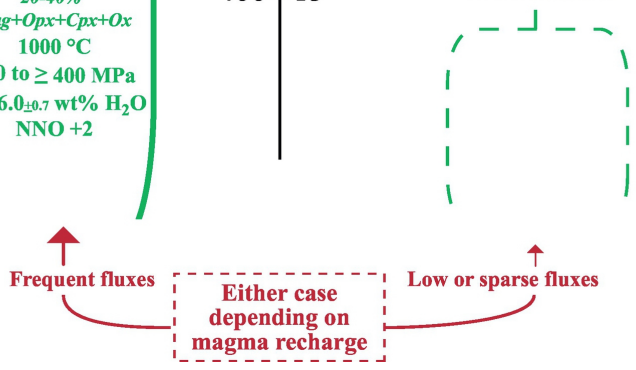

Figure 11 